\title{
DISCOVERY IN STATE ADMINISTRATIVE ADJUDICATION
}

No competent lawyer today would try a civil suit without first resorting to all available discovery techniques useful to his case. The opportunities which discovery ${ }^{1}$ offers for makmg trial "less a game of blindman's bluff and more a fair contest with the basic issues and facts disclosed to the fullest practicable extent," ${ }^{2}$ have made it an integral element in the civil adjudicative process. Yet, the attorney who must represent his client before a state agency which seeks to revoke a license, withdraw a franclise, determine whether it should allow an insurance benefit, or decide any of the manifold other administrative law questions is usually not able to utilize the discovery devices normally available in the courts. The situation is no better in the federal agencies. ${ }^{3}$ Although admimistrative agencies have access to a wealth of information by virtue of the broad investigative authority legislatively delegated to them, ${ }^{4}$ corresponding discovery procedures for the respondent are for the most part nonexistent.

In recent years commentators, greatly influenced by the success of discovery in civil litigation and disturbed by the apparent imbalance between parties in administrative adjudication, have urged federal agencies to adopt discovery rules. ${ }^{5}$ On the legislative front, Senator Dirksen unsuccessfully attempted to amend the Federal Administrative Procedure Act (APA) to allow depositions and discovery to the same extent as in civil proceedings except where the agency found such conformity "impracticable" and pro-

1 Unless otherwise noted, as herein used, "discovery" means the procedure and devices prescribed by Federal Rules of Civil Procedure 26-37, and followed to a great extent by most states having statutes on the subject, e.g., CAL. Crv. Pro. Code $\$ \S 2016-36$ (West Supp. 1966). The disclosure devices provided for by these rules are oral and written depositions, interrogatories, inspection and copying, physical examinations, and demands for admissions. While a realistic view of discovery may require a definition which encompasses "all available instruments of fact ascertaimment," Louisell, Criminal Discovery: Dilemma Real or Apparent?, 49 CAIIF. L. REv. 56, 61 (1961), such a broad definition presents many problems of uncertainty.

2 United States v. Proctor \& Gamble Co., 356 U.S. 677, 682 (1958).

3 See, e.g., Note, Discovery in Federal Administrative Proceedings, 16 Stan. L. Rev, 1035 (1964). Since 1962, the FTC's rules have been a major exception. 16 C.F.R. \& 3.31-.33 (1968). Recently, the FAA amended its rules to allow depositions in accordance with the Federal Rules of Civil Procedure. 14 C.F.R. $\$ 301.11$ (1967).

4 See, e.g., FTC Act, 15 U.S.C. $\$ \$ 46(a), 49$ (1964); Irr. ANn. STaT. ch. 43, § 108(3), (6), (8) (Smith-Hurd 1944); Ky. Rev. Stat. AnN. \& 183.100 (1962).

5 Berger, Discovery in Adninistrative Proceedings: Why Agencies Should Catch up with the Courts, 46 A.B.A.J. 74, 76-77 (1960); Kintner, Discovery in Administrative Adjudicative Proceedings, 16 AD. L. Rev. 233 (1964). The writers bave focused their attention almost exclusively on the federal agencies. One exception is a statutory proposal for administrative discovery in California. Comment, Discovery Prior to Administrative Adjudications-A Statutory Proposal, 52 CaIIF. L. REv. 823 (1964). 
vided otherwise by published rule. ${ }^{6}$ The Administrative Conference of the United States has recommended discovery to the agencies but would require them to adopt rules only to the extent "appropriate" to their proceedings. ${ }^{7}$

In California, the assembly passed administrative discovery bills in 1963 and 1965, but they died in the Senate Judiciary and Rules Committees. ${ }^{8}$ Both California proposals provided for the mandatory use of depositions and interrogatories. ${ }^{9}$ The State Attorney General, representing the

6 S. 1663, 88th Cong., 1st Sess. § 6(f) (1963).

7 Senate Subcomar. on Adamintstrative Practice and Procedure, Selected Reports of the Adaminstrative Conference of the United States, S. Doc. No. 24, 88th Cong., 1st Sess. 115, 117 (1963) [hereinafter cited as S. Doc. No. 24].

In recommending discovery only if "appropriate," the Administrative Conference refrained from going any further in Recommendation No. 30 than approval of "the principle of discovery." Report of the Coarmittee on Cosipliance and Enforcentent Procenedngs IN SUPPoRt or ReConsarendation No. 30 indicates that the final resolution was the product of much compromise. The Committee concluded that the practice of discovery, "modified as necessary in individual agencies, should be extended generally throughout the federal administrative establishment as a means of reducing delay and promoting fairness." $I d$. 138. The apparent intent was to prevent the agencies, by deciding merely that discovery was not appropriate, from eliminating it in its entirety.

The effectiveness of Recommendation No. 30 in bringing about change is doubtful. A progress report of the Agency Adjudication Committee of the ABA's Section of Administrative Law indicated a very slow response by the agencies to the principle approved by the Conference. 4 ABA-Section of ADMINISTRATIVE LAW 10 (1967). Of seventeen agencies polled, all of which had no discovery provisions prior to Recommendation No. 30, three agencies claimed to have carried out the recommendation, two agencies claimed to be in the process of installing discovery procedures, two agencies had "action pending," four agencies rejected the recommendation outright, and five agencies had "not completed their evaluation." Id. at 11. An analysis of the responses, however, makes it clear that most of the agencies considered themselves to have made discovery available if provision was made for prehearing conferences and subpoenas. Id. at 12. Provisions for the use of depositions and interrogatories were notably absent. These results point up the difficulty of trying to initiate action in the agencies by means of a compromise and ambiguous resolution from outside, where the agencies are opposed. It may be that anything short of a manifestation by Congress of a policy in favor of granting discovery rights to administrative litigants is insufficient. In fact, as the committee noted, it is difficult to conclude that the agencies were erroneous in their interpretation of the recommendation's language.

8 A.B. 3057, Cal. 1963 Sess. California Legislature, Final Calendar of Legislative Business 926 (1963). A.B. 25, Cal. 1965 Sess. California Legislature, Final Calendar of Legislative Business 36 (1965). Another attempt in 1963 was House Resolution 575, directing a study to be made of discovery in administrative procedure. There were no significant results. See California Legislature, Final Calendar of Legislative Business 1064 (1963).

9 A.B. 3067 , Cal. 1963 Sess. provided that any party inight take depositions of any person or serve written interrogatories upon any adverse party. The bill would have omitted from the California APA only those civil rules dealing with the taking of testimony of witnesses under foreign commissions, delay of proceedings due to difficulty of returning out-ofstate depositions, orders for inspection and copying and requests for admissions.

A.B. 25, Cal. 1963 Sess. would not have ounitted orders for inspections and copying. However, it required the party seeking to use any discovery device to obtain an order from the hearing officer after a showing of specific facts justifying discovery. A.B. $25, \S 11538$ 
agencies, opposed the introduction of discovery into administrative proceedings. ${ }^{10}$ Another bill is pending. ${ }^{11}$

Notwithstanding this legislative inaction, the California supreme court recently initiated certain clianges regarding discovery rules for administrative adjudicative proceedings. In Shively v. Stewart, ${ }^{12}$ Chief Justice Traynor, speaking for a unanimous court, interpreted "the Legislature's silence" to mean that it laad not rejected discovery in administrative proceedings, but had left to the courts the question of using the agency's subpoena power to secure prehearing discovery. ${ }^{13}$ The court did not mention the two bills which had died in the senate. Although the rules which the court announced are apparently himited in scope and somewhat uncertain in effect, ${ }^{14}$ the decision marks the first effort by a court to create rules for administrative discovery in the absence of statutory authority. The case thus raises the broader issue of the respective roles of the legislature and courts in effecting major change in administrative procedure. ${ }^{15}$ Perliaps of even greater significance is the question whether legislatures or courts in other states will respond to the policies underlying Shively and the above-mentioned legislative proposals or will view the public needs as demanding the maintenance of present policy.

The purpose of this Comment is to study the existing possibilities for

(as amended 1965). Unlike A.B. 3067, A.B. 25 made other procedural modifications in order to better adapt the civil discovery rules to the agencies.

10 Proceedings on Discovery in Administrative Procedures Before the California Assembly Interim Comm. on the Judiciary 50 (1964) [hereinafter cited as Discovery Proceedings]. The Attorney General's representative at the assembly's hearings asserted the agencies already had "quite a considerable discovery." Id. at 43. He suggested again that a discovery statute was superfluous a few moments later. See $i d$. at $\$ 1$. A questionnaire presented to the agencies using the services of the Office of Administrative Procedure (OAP) in Califorria revealed strong agency opposition to the most important discovery devices. OAP BULL., March-June 1965, at 18. Answers were received from agencies whose hearings made up $73 \%$ of the total number of proposed decisions by the OAP during 1964-65. Id. at 13. 98.7\% of the agencies were opposed to oral depositions, and $97.6 \%$ were opposed to interrogatories. The agencies were less opposed to demands for admission of facts or documents: $75 \%$ opposed to the former and $57 \%$ to the latter. As to inspection of specified documents $77.3 \%$ were opposed, while $57.1 \%$ were opposed to furnishing juames and addresses of persons believed to have knowledge of the issues.

11 S.B. 833, Cal. 1968 Sess. While the bill provides for interrogatories, there are no deposition provisions. The California State Bar opposes this bill because of this omission. Telephone conversation with R. Blair Reynolds, legislative counsel for the California senate committee on the judiciary, April 11, 1968.

1265 Cal. 2d 475, 421 P.2d 65, 55 Cal. Rptr. 217 (1966). For a discussion of this case and its implications, see The Supreme Court of Califormia, 1966-1967, 55 CALF. L. REv. 1059, 1068 (1967).

1365 Cal. 2d at 479, 421 P.2d at 67, 55 Cal. Rptr. at 219.

14 For a discussion of the discovery rules announced by the court in Shively, see notes 278-83 infra and accompanying text.

16 See section VB. infra. 
discovery in the state ${ }^{16}$ agencies and problems relating to expansion of discovery procedures. The author has chosen three types of agency adjudication ${ }^{17}$ to illustrate various consequences of administrative action, changing roles of the agency in the adjudication, and requirements of an administrative system of justice. Part I will examine the inevitable strain arising from an agency's desire to get results quickly and inexpensively, and the respondent's quest for procedural protection. Parts II, III, and IV are devoted to an analysis of the state of the law in three different adjudicative proceedings: License revocation and suspension-in which the state assumes a prosecutorial role and the controverted facts are adjudicatory; franchise withdrawal or modification-in which the state may or may not assume a prosecutorial role depending on whether the controverted facts are legislative or adjudicative; and the granting of industrial accident benefits-in which the state usually assumes the role of arbiter, although the disputed facts are adjudicative.

I

\section{INTERESTS IN CONFLICT: AGCNCY VS. RESPONDENT}

Professor Davis has stated that "probably no sound reason can be given for failure to extend to administrative adjudications the discovery procedures worked out for judicial proceedings." 18 Whether or not all arguments which opponents of discovery have advanced are sound, the extension of discovery to administrative adjudicative proceedings poses many problems, some of which are substantially different from those encountered in judicial proceedings. Is prehearing disclosure reconcilable with the public's interest in expeditious handling of administrative actions? Will discovery provide merely another weapon by which the agency hitigant may forestall admmistrative action and harass his opponent? Is administrative adjudication too complex for the application of discovery techniques? What happens to the agency's interest in protecting confidential information? And finally, ought there to be such a concern with the ability of the individual to prepare himself adequately when the subject matter of the action is neither vested property rights nor individual

16 Except where reference to federal agencies would aid an understanding of the situation with regard to state agencies, this study deals solely with state administrative proceedings.

17 As herein used, "adjudication" is synonymous with "contested case." The MODEL State APA § 1(3) (1946) and the Revised Moder State APA § 1(2) (Supp. 1966) define "contested case" as a proceeding before an agency in which the legal rights, duties, or privileges of parties are required to be determined after opportunity for a hearing. For the purposes of avoiding confusion, "adjudication," as used herein, does not include ratemaking, which is beyond the scope of this Comment. Both Model APA's define "contested case" to include ratemaking, but the Federal APA includes ratemaking under "rulemaking."

18 I K. Davis, Admonnistrative Law Treatrse § 8.15, at 589 (1958). 
liberty? Most of these questions are equally applicable to a license revocation proceeding, a withdrawal of a franchise and a hearing on accident benefits. This part will also discuss those problems involving only holders of franchises and licensees. A discussion of problems peculiar to individual types of adjudication is contained in the appropriate sections below.

Broadly stated, the argument for discovery is that the same conditions which inake the value of discovery so great in the courts are also found in administrative proceedings; outright rejection therefore is not justified. This was impliedly the view of the Committee on Compliance and Enforcement Proceedings of the Administrative Conference of the United States, which admitted that significant differences existed between the administrative process and the courts but nevertheless concluded that discovery was required. ${ }^{10}$ It is logical to expect discovery to be of at least some aid in agency adjudication.

State agencies cannot, moreover, rely on a statutory prolibition of certain kinds of discovery similar to the legislative restriction which shields federal agencies. ${ }^{20}$ Therefore, state agencies cannot claim that the legislature has prohibited the adoption of discovery. Furthermore, the agencies unust contend with their failure to be thorouglily consistent in opposing discovery procedures while operating nnder biberalized rules of evidence. Many state agencies, following the test of the Model Acts, ${ }^{21}$ admit evidence if it is of a type "commonly rehed upon by reasonably prudent men in the conduct of their affairs." ${ }^{22}$ This results in the irony that, in the courts, a party nay discover information despite his not being able to use it at trial, ${ }^{23}$ but in the agencies he may use it at the learing despite his not being able to discover it. The situation in the courts, however, is at least somewhat rational in that it promotes the discovery of admissible evidence. ${ }^{24}$ In terms of contact with all types of evidentiary

10 See S. Doc. No. 24, supra note 7, at 121, 138.

20 The Jencks Act, 18 U.S.C. $\S 3500$ (1964), provides for production of a witness's statements made to the government in connection with a criminal prosecution. Since the rule becomes operative only after the witness has testified, discovery is precluded. Id. $\$ 3500$ (a). The case from which the statute is derived, Jencks v. United States, 353 U.S. 657 (1957), as modified by the statute to expressly preclude discovery, has been held applicable to administrative proceedings. See, e.g., NLRB v. Adhesive Prods. Corp., 258 F.2d 403 (2d Cir. 1958); Great Lakes Airlines, Inc. v. CAB, 291 F.2d 354, 365 (9th Cir.), cert. denied, 368 U.S. 890 (1961). Supp.).

21 Moder State APA, 9C U.L.A. (1957) ; Revised) Modet State APA, 9C U.L.A. (1966

22 Model State APA § 9, 9C U.L.A. (1957); Revised Modet State APA $\S 10$, 9C U.L.A. (1966 Supp).

23 Compare, e.g., Car. Crv. Pro. Code $\S 2016$ (b) (West Supp. 1966) (scope of inquiry), with id. \$2016(d) (use of deposition).

24 See CaI. Civ. Pro. Code $\S 2016$ (b) (West Supp. 1966), providing that "[i]t is not ground for objection that the testimony will be inadnissable at the trial if the testimony sought appears reasonably calculated to lead to the discovery of admissable evidence." 
materials then, the court's adoption of discovery rules was a far greater departure from prior practice than would be their adoption in administrative proceedings where, theoretically at least, parties may deal with the evidentiary materials at some stage of the proceedings.

Emphasizing still further the contrast between the policy of rejecting discovery in the agencies and liberal rules regarding other aspects of procedure are the relaxed rules of pleading which the courts have imposed on administrative proceedings. ${ }^{25}$ One justification for a corresponding relaxation in the courts has been the almost unversal use of discovery. ${ }^{26}$ But relaxing pleading rules in administrative adjudication without concomitantly allowing discovery may often have the effect of keeping the respondent in the dark. ${ }^{27}$

\section{A. Complexity, Informality, Confidentiality, and Imbalance}

\section{Complexity}

Opponents of administrative discovery have asserted that the complex nature of agency hitigation makes discovery impracticable. ${ }^{28}$ Not only will it provide the respondent with an additional means of delaying and harassing the agency, but more importantly, it is ineffective in ordering the complex proceedings. ${ }^{29}$ The argument implies that the very nature of the adjudication precludes using discovery to expedite the hearing. The discovery mechanisn, instead of ordering the mass of detail in the complex case, becomes just another procedural gimmick. However, this argument presupposes two dubious facts: First, that there is something inherent in the nature of administrative proceedings which inakes them complex, or that "the cardinal feature" of the agency process is the large

25 See, e.g., Branch Banking \& Trust Co. v. Wilson County Bd. of Educ, 251 N.C. 603, 111 S.E.2d 844 (1960); Gray Well Drilling Co. v. State Bd. of Health, 263 Wis. 417, 58 N.W $2 d 64$ (1953).

20 In Hickman v. Taylor, 329 U.S. 495 (1947), the Supreme Court noted that the effect of liberal discovery rules was to restrict the role of pleadings to giving general notice. Id. at 501.

Although most states' pleading requirements are somewhat stricter than Federal Rule of Civil Procedure 8(a), they are still broad enough to enable the courts to relax pleading rules. See, e.g., Handley v. Capital Co., 152 Cal. App. 2d 758, 313 P.2d 918 (1957).

27 See Discovery Proceedings, supra note 10, at 5-8, 40. On the inadequacy of the pleadings in giving notice, one legislator remarked, "The Legislature . . Inust have assumed that the accusation would meet the test [of setting forth in ordinary and concise language the acts or omissions with which the respondent is charged in order that the respondent prepare his defense], although the accusations I have seen have never come close to meeting it." Id. at 14 (remarks of Assemblyman Danielson). Additional support came from the Presiding Officer of the Office of Aduninistrative Procedure. Id. at 70-71.

28 See President's Conference on Administrative Procedure, Report of the Chairman of the Committee on Pleadings, in 14 FED. 'Com. B.J. 99, 101 (1955) (Mr. Westwood).

29 See, e.g., id. at 104 (Mr. McAllister). 
case. ${ }^{30}$ The reality of administrative adjudication, not only in the states, where the typical case is likely to be far shorter in duration than cases in the courts, but also in the federal agencies, is not in accord with these assumptions. ${ }^{31}$ It is in direct conflict with the common view that administrative procedures are speedier than those of the courts..$^{32}$ Regulated businesses can of course be large and complex; many cases involving these businesses will therefore tend towards complexity and lengthy duration. The same problem, however, exists in the courts. ${ }^{33}$

If complexity exists in an agency proceeding, it is usually because the agency is considering a big case. Moreover, the techniques the Administrative Conference of the United States recommends for handling the protracted case are directly contrary to the second assumption-that the big case is incapable of expedition. ${ }^{34}$ The Conference recommended that agency litigants have discovery rights whenever they are necessary to enable the parties to discuss the issues intelligently. ${ }^{35}$ The Conference determined that attempts to "surprise" an adversary were ordinarily fatuous; hiberal discovery riglits therefore seemed necessary. The big case requires firn control, however, and for that reason the recommendation requires the parties to submit written statements clarifying their positions. ${ }^{36}$ These statements would be the subject of prehearing conferences, from which would emerge the boundaries of discovery. ${ }^{37}$ The Conference's prescription provides for modification of discovery orders pursuant to changes of a party's tentative statement of the issues. ${ }^{38}$

The Conference, then, viewed discovery as a necessary and practicable means by which to define issues and thereby simplify proceedings. To make it effective, the trial examiner's firm hand must guide it, but this limitation on discovery is only one part of his firm control of the entire proceedings. ${ }^{39}$ The conclusion seems warranted that, standing alone, complexity does not delineate a novel feature of administrative cases which

30 Id.

31 See generally K. Davis, Aduinistrative Law: Cases-Text-Problems 3-4, 15 (1965).

$32 \mathrm{~K}$. Davrs, ADMrNistrative LAW TeXt § 1.05, at 16 (1959).

33 See, e.g., the protracted litigation between the Government and the Aluminum Company of America, discussed in P. Areeda, Antitrust Anatysis: Probrems, Text, Cases 7778 (1967). The litigation spanned a period of eight years, and the trial record consumed more than 58,000 pages. Id.

${ }^{34}$ See genzerally Administrative Conference of the United States, Committee on Information and Education, Recommended Procedures for Protracted Hearings Before Administrative Agencies (2d Draft 1963).

$35 \mathrm{Id}$. at 17.

36 Id. at 18.

37 Id.

38 Id.

39 Id. at 11-13. The Conference's recommendation, urging the hearing officers to be "iron hearted judges" at all stages of the hearing, seems particularly appropriate as to discovery. 
points to the inapplicability of discovery. Complexity was in fact one reason for adopting discovery in the courts. ${ }^{40}$

\section{Informality}

A significant distinction between state administrative adjudication and litigation in the courts lies in the former's relative informality, at least in the routine case. This informality may make formal discovery unnecessary because many agencies have a policy of fair dealing which assures the respondent of access to vital information. ${ }^{41}$ In numerous instances, the agency has neither evidence to hide nor any interest in doing so. Furthermore, reliance on formal discovery in agencies which provide informal means of discovery may have the unfortunate effect of undermining the infornality of the entire adjudication. Even in federal agencies, where the nature of the proceedings is likely to be more formal and adherence to the rules more strict, ${ }^{42}$ the agencies may in fact voluntarily provide the respondent with more information that the rules require. ${ }^{43}$

The agency's fairness and willingness, in many cases, to give the respondent all that he needs, lowever, does not argue for the superfluity of discovery. A practice of informal discovery in which the importance of the case, the agency's opinion of the morality of the adversary, the individual predilections of the prosecutor and his opinion of the trustworthiness of the opposing counsel influences the agency's decisions, is so unpredictable and discriminatory that it seens patently unjust. In rejecting such a system of informal discovery in the criminal law, Chief Justice Traynor asserted that only an impartially administered pretrial discovery schenie free of adversary considerations of trial strategy can operate effectively. ${ }^{4}$ Although informal procedures nuay provide many respondents with nuch needed information, a system of discovery which will protect all equally can be grounded only on the firmer foundation of rules of law.

\section{Confidentiality}

Both the agency and the public have an interest in protecting sources of inforniation. A major function of the agencies is to police matters of vital concern to the public, and, like other policing organizations, they

40 See Developments in the Law-Discovery, 74 Harv. L. REv. 940, 944-46 (1961).

41 See Discovery Proceedings, supra note 10, at 43, 46, 51; President's Conference on Administrative Procedure, Report of the Chairman of the Committee on Pleadings, 14 FED. CoM. B.J. 99, 102-03 (1955) (Mr. Funston).

42 Cf. 1 F. Cooper, State Adarmistrative Law 4 (1965).

43 See S. Doc. No. 24, supra note 7, at 132.

44 Traynor, Ground Lost and Found in Criminal Discovery, 39 N.Y.U.L. Rev. 228, 23738 (1964). 
must protect the threatened individual as well as rely on his cooperation. Regulatory agencies have often been the poor man's friend. The small businessman and the victim of sharp dealing or corrupt practices often instigates investigations. ${ }^{45}$ Where these people have given information to the agencies in confidence, public policy seems to require the agencies to keep their names-and often their statements-secret. Like the problem of protracted trials, however, privileged information is not a dilemma unique to the agencies. ${ }^{46} \mathrm{~A}$ procedure which would allow unlimited rifling of agency files would vitiate the policy of protecting sources of information for all government bodies. The fact that the state is usually a party to agency adjudication indicates only that questions of government privilege-both intricate and routine-will arise with greater frequency in the agencies than in the courts. There is little basis for predicting qualitative differences in the privilege problems which discovery will engender in the agencies.

Commentators have discussed the problem of government privilege extensively. ${ }^{47}$ The conclusion of authors, juclges, and legislators is that it is not insoluble. ${ }^{48}$ It bears repeating that the process of balancing the interest of the respondent in having access to relevant information against the interest of the public in safeguarding its reservoirs of information is one which can take place in the agencies as well as the courts. ${ }^{40}$ The nature of the proceeding, the character of the acts of informing, the availability of other sources of information, the potential for harassment, the informer's reliance on officials prior to his informing, and the importance of the material to the party seeking disclosure are factors which the agency takes into account when its counsel. invokes the informer privilege. ${ }^{50}$ It could just as easily apply the same balancing test to a request (1963).

45 See J. Patamountain, The Dotch Case and the Frderat Trade Comonssion 4-6

46 See Louisell, Criminal Discovery: Dilemma Real or Apparent?, 49 CALIF. L. REv. 56 (1961); Developments in the Law-Discovery, 74 HARv. L. Rev. 940, 1009-20 (1961).

47 Berger \& Krash, Government Immunity from Discovery, 59 YALE L.J. 145I (1950); Gardner, Privilege and Discovery: Background and Development in English and American Law, 53 GEo. L.J. 585 (1965); Comment, Discovery of Information in Possession of Govermment Agencies and Bureaus Over a Claim of Privilege by the Government, 13 O\#ro ST. L.J. 270 (1952); Note, Discovery from the United States in Suits Between Private Litigants -The 1958 Amendment of the Federal Housekeeping Statute, 69 Yars L.J. 452 (1960).

48 See, e.g., Berger \& Krash, Government Immunity from Discovery, 59 YArE L.J. 1451, 1463 (1950).

49 See S. Doc. No. 24, supra note 7, at 133-38.

50 The leading case on the mformer privilege is Roviaro v. United States, 353 U.S. 53 (1957), in which the Court held that the privilege was a qualified one. California has reently gone very far in limiting the privilege in criminal cases. See, c.g., Priestly v. Superior Court, 50 Cal. 2d 812, 330 P.2d 39 (1958); People v. Garcia, 250 A.C.A. 39, 58 Cal. Rptr. 60, reversing on rehearing 242 A.C.A. 898, 51 Cal. Rptr. 810 (1966). 
for discovery. And a similar balancing process would be appropriate where other privileges are asserted.

The possibility of the agency's using much the same balancing test for discovery of its records as it uses during the actual proceedings is made reasonable by the ability of agencies which conduct much of their litigation in court, such as the NLRB, to retain their needed confidentiality, even though they are subject to the same discovery devices as are other parties. ${ }^{61}$ The Model APA suggests a rule of privilege which is easily applicable to agency discovery procedures: The agencies shall give effect to the rules of privilege, sucl as the informers and work-product privileges, which the law recognizes. ${ }^{52}$ This rule would protect the public's interest in confidentiality and still allow discovery.

\section{Imbalance}

In light of the existing broad investigative and subpoena powers which the agencies already enjoy, ${ }^{53}$ as well as the commanding position that inheres in the role of any public prosecutor, a state agency is likely to enjoy an advantage at the outset of any adjudicative hearing. The agency's interest lies in preserving the imbalance; it is therefore probably futile to attempt to convince the agencies that discovery would benefit them.

To win the argument, the proponents of discovery must appeal to the legislature's or court's sense of fairness. Fairness in adjudication is also part of the public interest to whose pursuit the agencies are already committed. There are at least three arguments hinking fairness with discovery. First, in terms of resources, it is often the case that only the agency has the ability to enter the hearing with extensive information. This is a product both of an imbalance in physical resources such as money and manpower-the significance of which is accentuated in state agencies by the fact that the subject of agency regulation is often an individual craftsman or proprietor rather than a major industry or large corporation ${ }^{54}$

51 See Olson Rug Co. v. NLRB, 291 F.2d 655 (7th Cir. 1961) (production ordered in contempt proceeding); NLRB v. Capitol Fish Co., 294 F.2d 868 (5th Cir. 1961) (investigator ordered to testify where statements given to him were claimed to be false).

v2 Model State APA \& 9(1), 9C U.L.A. (1967); Revised Moded State APA § 10(1), 9C U.L.A. (Supp. 1967).

This was in fact the solution adopted in California's proposed discovery bills. $A B$ 3067, Cal. 1963 Sess. and AB 25, \& 11537, Cal. 1965 Sess. would both have applied the rules of privilege applicable at law.

E3 See, e.g., Ind. Ann. Stat. § 63-3007 (1961); Mich. CoMrp. Laws ANn. § 259.51(f) (1967).

54 Of the groups specifically enumerated as covered by California's APA, almost all fall into the category of individual craftsmen, proprietors, and professionals. See Cac. Gov't CODE $\S 11501$ (b) (West 1966). Typical of these groups are dentists, doctors and surgeons, accountants, barbers, cosmetologists, embalmers, dry cleaners, sharthand reporters, and various groups of people engaged in alcoholic sales. $I d$. While it is possihle that some of 
and of the agency's authority to gain access to relevant information. ${ }^{65}$ Second, despite the usual prohibition on ex parte communications, the concentration of functions within agencies enliances the possibility of information being transmitted, even if only inadvertently, to the hearing officer without opportunity for the respondent to rebut. ${ }^{\text {to }}$ Third, it is important that those whom the agencies regulate slould have confidence that the administrative system has the capacity for doing justice. Because the agencies lack funds to police adequately the regulated area, the agencies nust rely on voluntary compliance with regulations. ${ }^{57}$ Such reliance depends, in turn, on a belief among those regulated that the administrative agency proceeds in its regulatory tasks in a manner consistent with generally leeld notions of fairness. If only the agency has access to the facts at issue in an adjudication, the confidence of those who must live by the administrative system is sliaken.

Discovery may have some advantages for the agency as well as the respondent. Through the use of discovery techniques agencies might, for example, be able to learn of materials of whose existence they were unaware. The fact of continuing agency opposition to discovery by respondents, however, is evidence that the agencies believe they can only lose by its adoption. This fear is not without support. One reason explaining the adoption of discovery in the civil courts much sooner than in the agencies is that in civil cases the two parties lave an equal interest in the applicable procedures, and stand to gain or lose about equally from modifications and adoption of new rules. ${ }^{68}$ However, this situation may not obtain in administrative proceednigs ${ }^{69}$ where a respondent's attorney may lave little or no familiarity with the agency's procedures. And agencies may stand to lose their tactical advantage anytime they must disclose information. Since the agencies are adversaries, it should come as no surprise that they are unwilling to remove the imbalance between the parties to adjudication. Moreover, it is difficult for a governmental body which is convinced that it is acting for the public interest to favor granting greater weaponry to its opponents. This serves to intensify the usual opposition of an adversary who stands to lose by the adoption of new procedures.

Discovery ensures that, to the greatest extent possible, the parties will

these activities can involve large scale operations, such operations would more likely come within the federal regulatory scheme.

55 S. Doc. No. 24, supra note 7, at 126.

66 The facts of concentration of functions in the agencies and differing resources were considered by the court in Shively v. Stewart, 65 Cal. $2 \mathrm{~d} 475,479-80,421$ P.2d 65, 68, 55

Cal. Rptr. 217, 220 (1966), as militating for administrative discovery.

67 Cf. Fuller, Positivism and Fidelity to Law-A Reply to Professor Hart, 71 Hanv. L. REv. 630 (1958).

${ }^{58}$ See S. Doc. No. 24, supra note 7, at 126.

$59 \mathrm{Id}$. 
enter combat on equal terms, and may also enable the respondent to understand that the accusation marks the commencement of adjudication rather than a final determination of guilt. It provides at least the means for bridging the resources gap. As noted above, there is little reason to believe the complex nature of certain administrative cases or the requirements of privilege pose problems unique to the agencies. Nor is it likely that the value of informal procedures will be vitiated, since respondents would probably still rely on informal devices where they are available.

\section{B. Expedition}

Mention has been made of the problem of delay in connection with the "big" case. ${ }^{00}$ Critics of discovery in administrative proceedings consider the delay potential of discovery a leading argument against its adoption in all admimistrative cases, whether having to do with a license, franchise, or financial compensation. ${ }^{61}$

The success of discovery in expediting the trial of civil cases might easily lead to the conclusion that, despite qualitative differences in the nature of the two processes, discovery is bound to contribute in some degree towards expediting agency affairs. To the extent discovery educates the parties, simplifies issues, stimulates settlements, and discourages parties from unproductive inquiry at trial, it seems to be equally useful in all adjudication. This in fact is the conclusion that the Administrative Conference's Committee Report reached in support of its discovery recommendation $^{62}$ for federal agencies. Judge Kaufman ${ }^{63}$ of the United States Court of Appeals for the Second Circuit, and the United States Attorney General's Committee on Administrative Procedure ${ }^{6 t}$ have also

60 See text accompanying notes 28-30 supra.

61 See President's Conference on Administrative Procedure, Report of the Chairman on Pleadings, in 14 Fed. Coar. B.J. 99, 104 (1955) (Mr. McAllister).

62 S. Doc. No. 24, supra note 7 , at 138.

63 Speaking of the pretrial conference, Judge Kaufman writes that the greatest procedural problem both courts and agencies face is that of defining the issues to be tried. Kaufman, Have Administrative Agencies Kept Pace with Modern Court-Developed Techniques Against Delay?-A Judge's View, 12 AD. L. Rev. 103, 106 (1959-1960). On the basis of the success achieved with the pretrial conference in the courts, he urges the agencies to give the device a chance. $I d$. at 109-10. Because the prehearing conference would be ineffective and futile without discovery techniques, however, Kaufman concludes that the agencies had better "[reject] the old bugaboo . . . that all bitigants should be treated as though they were Al Capone," and accept discovery too. Id. at 114-16.

${ }^{64}$ Final Report of the Attorney General's Comanittee on Adminustrative ProceDURE, S. Doc. No. 8, 77th Cong., 1st Sess. (1941). The Committee found that "perhaps the most fruitful possibilities for expediting and simplifying formal administrative proceedings lie in the field of prehearimg techniques." Id. at 64. It noted that through pretrial hearings courts have simplified, shortened, and frequently avoided trials. Based on a sampling of benefit proceedings almost exclusively, they concluded that "[s]imilar results from similar procedures are obtainable by administrative agencies." Id. at 65 . 
concluded that pretrial procedures which expedite matters in courts would have a like effect in agencies.

Although the creation of a system of administrative adjudication was in part an attempt to provide a more flexible and less traditional procedure than was available in the courts, ${ }^{65}$ all procedures which the courts use are not, ipso facto, impediments to expeditious handling of cases. In the years since adıministrative agencies proliferated en masse, the courts have made strides towards expeditiously handling their ever increasing caseloads and discovery is one of the most important of the techniques developed..$^{68}$ Furthermore, it is arguable that introducing discovery procedures may allow the agencies a wider latitude in selecting cases for prosecution. Because of manpower and money restrictions, the agencies inust ordinarily be extremely rigorous in their methods of selecting cases, with the result that the agency can often prosecute only the most derelict of violators. ${ }^{67} \mathrm{~A}$ procedure which allows for disclosure of the relevant facts before a hearing, when conducted within a system which emphasizes informal adjudication and summary disposition, has the attraction of allowing the agencies to relax somewhat their stringent standards for prosecuting cases. The time which the agency saves by eliminating the need for many hearings more than compensates for the time lost in taking depositions or writing interrogatories.

The fact that the informality of state agency adjudication is but a part of its shorter duration and more loosely organized nature in gen$\mathrm{eral}^{\mathrm{BS}}$ adds weight to the recommendations of the Administrative Conference, Judge Kaufman, and the Attorney General's Committee. The practice of conducting a "trial at intervals"- - the procedure whereby the agency grants long continuances at various stages of the hearing-which some have thought to justify the rejection of discovery in the federal agencies, ${ }^{89}$ does not exist in the ordinary state license revocation or suspension proceeding. ${ }^{70}$ Because federal agencies grant continuances liberally after the agency presents its case-in-chief, opponents of discovery have argued that a respondent will have sufficient time to prepare his (1943).

${ }^{65}$ See the dissenting opinion of Justice Frankfurter in FCC v. NBC, 319 U.S. 239, 248

${ }^{68}$ An excellent analysis of the expediting function of discovery is contained in Greyhound Corp. v. Superior Court, 56 Cal. 2d 355, 364 P.2d 266, 15 Cal. Rptr. 90 (1961).

${ }^{67}$ See 1 F. Cooper, STate Admmistrative Law 318 (1965).

68 See id. at 4.

${ }^{69}$ See Standard Distribs., Inc. v. FTC, 211 F.2d 7, 11 (2d Cir. 1954); President's Conference on Administrative Procedure, Report of the Chairman of the Committee on Pleadings, 14 FED. COMr. B.J. 99, 102 (1955) (Mr. Westwood).

${ }^{70}$ See Clarkson, Practice Before California Licensing Agenties, 44 CALIF. L. REv. 197, 203 (1956). 
case. ${ }^{71}$ And he will have heard at the hearing all he sought to learn by means of discovery. The fact that the Federal Trade Commission adopted discovery rules soon after it dispensed with the "trial at intervals" method of adjudicating cases is often cited as proof that the absence of discovery techniques in administrative adjudication is compatible with the pohicy of conducting agency actions with the utmost regard for the respondent's interest in adequately preparing his defense. ${ }^{72}$

In a proceeding in which a matter of hours or a few days is sufficient for determining the relevant adjudicative facts, a policy of liberally granting continuances would not be justifiable. In fact, state courts do not favor such a procedure. ${ }^{73}$ Furthermore, it is questionable whether such a procedure would be justifiable in any case, because there is good reason to beheve the duphication of effort necessary after beginning a hearing again substantially impedes the expeditious disposition of the case. ${ }^{74}$ Thus, without "trial at intervals," the respondent's need for information which would expedite the proceedings seems to require rules of discovery.

To some, the short duration of most state administrative hearings might seem to militate against introducing discovery as a remedial measure against delay. While in sonve instances withdrawing a statewide franchise may be similar to a protracted learing in the courts or federal agencies, most licensing and workmen's compensation proceedings deal with cases which typically involve a single individual and relatively simple adjudicative issues. Licensing cases involving physicians serve as a good example. Calfornia's Attorney General, in opposing the extension of discovery to the agencies, has cited statistics compiled by California's Office of Administrative Procedure showing that during the fiscal year 1961-1962 administrative cases before the Board of Medical Examiners averaged less than four hours. ${ }^{75}$ It is lighly doubtful that the taking of depositions, interrogatories, and possible inspections of documents would improve this average. The Attorney General estimated that the discovery procedure which the California suprene court created in Shively, and which would require an especially cumbersome method for reviewing discovery meth-

11 Cf. S. Doc. No. 24, supra note 7, at 129.

72 See L.G. Balfour Co., 62 F.T.C. 1541, 1543 (1963).

${ }_{73}$ See, e.g., Clarkson, Practice Before California Licensing Agencies, 44 CarrF. L. Rev. 197, 203 (1956); Discovery Proceedings, supra note 10, at 74.

74. "It would require a great deal of ingenuity to devise a system which would result in a greater waste of the time of the hearing examiner and the litigants [than the trial at intervals methods]." Kaufman, Have Administrative Agencies Kept Pace with Modern CourtDeveloped Techniques Against Delay?-A Judge's View, 12 AD. L. REV, 103, 115 (19591960).

75 Petitioner's Brief for Rehearing at 23, Shively v. Stewart, 65 Cal. 2d 475, 421 P.2d 65, 55 Cal. Rptr. 217 (1966). 
ods, ${ }^{76}$ would result in delays of six months to two years before matters finally reach administrative hearings on the merits; ${ }^{77}$ because of this, he argued that such discovery procedures undermined the legislature's very intent in providing for administrative adjudication and were at war with the purpose of administrative law. ${ }^{78}$ In another instance, the Attorney General's Office has estimated the delay which the usual discovery rules would cause in the average case to be six to nine weeks. ${ }^{70}$

Given the normal requirements of practice for discovery techniques, it would not be surprising to find that discovery resulted in delay in agencies which can arrange a hearing soon after filing the notice or accusation. In California for instance, the defendant in a court case may take a deposition at any time after service of process, ${ }^{80}$ but must give at least ten days notice. ${ }^{81}$ Plaintiffs cannot take a deposition in the normal case until twenty days have elapsed. ${ }^{82}$ The defendant may serve interrogatories after service of process, but an adversary has fifteen days to submit answers. ${ }^{83}$ The plaintiff cannot serve his interrogatories for ten clays and, therefore, the defendant need not submit answers until twenty-five days have elapsed. The number of sets of interrogatories is not limited "except as justice requires to protect the party from annoyance, expense, embarrassment or oppression." "84

While it is possible to eliminate the requirement of giving notice to the agency, answers to lists of interrogatories will require time for either party. The twenty and ten day prohibitions on the plaintiff's use of discovery seem necessary at least in cases where the defendant has not known of or prepared for the pending hitigation. Even if neither party refuses to make discovery, there may be delay in cases where hearings are possible soon after notice is filed, since even smooth operation of discovery takes many weeks. ${ }^{85}$ If there is such a refusal, or if, as routinely

76 The court denied the hearing officer discretionary authority to limit discovery orders. Consequently, the agency must appeal to the courts to seek limitations on discovery. Shively v. Stewart, 65 Cal. 2d 475, 480, 421 P.2d 65, 68, 55 Cal. Rptr. 217, 220 (1966). This seems to require substantial delays.

77 Petitioner's Brief for Rehearing at 24, id.

78 Id.

${ }^{79}$ See Discovery Proceedings, supra note 10, at 45-46. In the "average case" discussed, which was based on the very congested agencies in Los Angeles, it takes four months from accusation to hearing. $I d$.

80 CAL. Civ. Pro. Code $\$ 2016$ (a) (West Supp. 1967).

81 Id. § 2019 (a) (1).

82 Id. § $2016(\mathrm{a})$.

83 Id. \$ 2030(a).

84 Id. § 2030(b)

85 If the plaintiff serves two sets of interrogatories upon his adversary, for example, discovery may not be completed until almost seven weeks have elapsed. See id. $\$ 2030$ (a) (b). 
occurs, there is difficulty in arranging a date for the taking of depositions, either because the respondent is intent on obstructing the proceedings or because his counsel has a busy schedule, there may be delay even in the case where hearing dates are set for long after the filing of the notice.

One possible solution to these problems is to give the hearing officer broad discretionary authority to make discovery orders and orders for the parties' protection. ${ }^{86}$ Yet, courts may be reluctant to vest any such discretionary authority in the hearing officer. ${ }^{87}$ Instead, it is placed in the courts with resulting delay while the parties make time consuming appeals from the agencies to the courts on prehearing motions. ${ }^{88}$

The extent to which delay will occur is a factor weighing against introducing discovery into administrative agences. Although the administrative process has other justifications besides the speed with which it dispenses justice-flexibility of sanctions, expertise, uniformity of application-the value to the entire judicial system of expeditious proceedings cannot casually be disregarded.

However, expedition can be treated as an end in itself only at the risk of sacrificing more basic purposes of agency administration. Even if it is demonstrated that discovery delays proceedings, the favorable attributes of discovery must also receive weight. For example, in criminal cases the courts also have a great interest in expedition. Yet, no one has justified the increasing adoption of discovery rules in criminal proceedings ${ }^{89}$ in terms of what it will do for dockets, but rather in terms of what it will do to ensure a fair trial for defendants. Expedition is justifiable only insofar as the greater efficiency in the administrative process ultimately means a greater degree of justice. There is no sense in expediting for the purpose of according justice, only to find that by so doing an essential ingredient of fairness-the right to prepare and know the evidence-no longer exists. For reasons of fairness the need for expedition does not undermine the need for discovery. Furthermore, in many cases, discovery will actually expedite the adjudication. ${ }^{90}$

${ }^{86} \mathrm{~A}$ discussion of the possibility of giving the hearing officer such discretionary authority is contained in Part V A infra.

87 In Shively v. Stewart, 65 Cal. 2d 475, 421 P.2d 65, 55 Cal. Rptr. 217 (1966), the California Supreme Court relied on past cases holding the issuance of a subpoena to be a ministerial act in ruling that the agency and the hearing officer has no discretionary authority even where subpoenas are sought for discovery purposes. Id. at $480,421 \mathrm{P} .2 \mathrm{~d}$ at 68, 55 Cal. Rptr. at 220.

88 In Shively v. Stewart, the court held, 65 Cal. 2d 475, 421 P.2d 65, 55 Cal. Rptr. 217 (1966), that the agency "can move to quash, vacate, or modify the subpoena in the superior court if the subject inatter is privileged or the subpeona is too borad;" only at the hearing does the hearing officer have discretion.

80 See discussion in section C 2(b) of this Part.

90 See notes 62-66 and accompanying text. 


\section{Discovery by Compulsion}

In previous sections, this Comment has discussed the wisdom of providing discovery in state administrative proceedings as a matter of policy. It will now suggest that the state agencies may be compelled to provide rules of discovery in certain administrative proceedings as a matter of constitutional law. The argument, in brief, is that administrative agencies, like other state tribunals, must accord their litigants certain fundamental rights, that those agencies which initiate essentially adjudicative proceedings must accord their litigants the same procedural rights enjoyed in a criminal context, ${ }^{p 1}$ and that because discovery may be one of those procedural protections to which criminal defendants are constitutionally entitled, it may well be one which certain agencies must afford.

\section{The Applicability of the Constitution in Administrative Proceedings}

Individuals who seek greater protection in administrative proceedings -especially those possessing occupational licenses and governmental franchises ${ }^{22}$-often confront the doctrine of privilege. According to that doctrine, agencies dispense governmental largess in which the recipient has no vested right but only a conditional privilege. ${ }^{.3}$ And because the franchise or license is not a vested right, the agency may grant, condition, or revoke it without observing the procedural protections which "due process" requires. ${ }^{94}$ Althougl most states today reject the distinction insofar as it would allow denial of a hearing, ${ }^{95}$ the idea that the public interest conditions all officially authorized activity has continuing importance today insofar as it justifies procedural shortcuts in the agencies. ${ }^{90}$

The demise of the doctrine of privilege might, on the other hand, give to the holders of government certificates a status approaching that of the owner of property. The effect of such status would be substantial: Gov-

${ }^{91}$ See Greene v. McElroy, 360 U.S. 474 (1959).

92 For reasons discussed at notes 337-44 infra and accompanying text, the need for additional procedural protections in workmen's compensation proceedings is not as urgent as in license and franchise cases.

${ }^{93}$ See King v. Harris, - Ind. App. 一, 212 N.E.2d 387 (1965).

94 "Due process of law applies to a deprivation only. If a person is not engaged in a business and has no enforceable right to enter upon it, he is not deprived of a right if he is denied the privilege. Since there is no right ... the customary elements of due process of law are not required for valid denial of the privilege." In re Carter, 192 F.2d 15, 19 (D.C. Cir. 1951) (Prettyman, J., dissenting).

95 See 1 F. COOPER, State AdMINISTRatTVE LAW 144-45 (1965).

${ }^{96}$ See generally Reich, The New Property, 73 YaLE L.J. 733, 739-46 (1964). Whether the official theory supports the privilege doctrine or not, however, a statute which provides for suspension or revocation of a liquor license if the agency "be of the opinion that ... [t] he license is not a suitable person to hold such license," S.C. Cone ANv. \& 4-54(1) (1962), must necessarily create a very uncertain privilege. 
ernment agencies seeking to withdraw an authorization to conduct certain activities would have to meet relatively stringent procedural standards, designed to assure the recipient of a fair hearing. ${ }^{97}$ These standards might include the opportunity to gain access to needed information before the hearing.

Despite the continuing recital of the privilege doctrine in recent years ${ }^{98}$ the theoretical distinction between privilege and right has not allowed the agencies to withstand the onslaught by the courts against lax procedures. Decisions in both state ${ }^{99}$ and federal ${ }^{100}$ courts have demanded adherence to constitutional requirements. ${ }^{101}$ Although most of the cases deal only with the right to a hearing, recognizing such an elemental right ultimately leads to the recognition of additional rights. ${ }^{102}$

Since the turn of the century California had described the right to practice a profession after satisfying the entrance requirements as a vested property right. ${ }^{103}$ Finally, in a 1952 decision, ${ }^{104}$ the state supreme court declared that the law contemplated justice whether the state granted a license as a privilege or a right. The court ordered the state to accord the petitioner an opportumity to present the merits of her application even though her occupation consisted only of operating a game of amuse-

97 The Supreme Court has held that an individual covered by the property clause of the fourteenth amendment has a "right to a fair and open hearing ... as a minimal requirement. ... There must be due notice and an opportunity to be heard, the procedure must be consistent with the essentials of a fair trial, and the agency must act upon evidence and not arbitrarily." Railroad Comm'n v. Pacific Gas \& Elec. Co., 302 U.S. 388, 393 (1938).

08 See, e.g., King v. Harris, - Ind. App. -, 212 N.E.2d 387 (1965); Sutherland v. Ferguson, 194 Kan. 35, 397 P.2d 335 (1964).

90 See generally Fascination, Inc. v. Hoover, 39 Cal. 2d 260, 246 P.2d 656 (1952);

Brown v. Murphy, 34 Misc. 2d 151, 224 N.Y.S.2d 423 (Sup. Ct. 1962).

100 See, e.g., Greene v. McEIroy, 360 U.S. 474 (1959).

101 Professor Reich has suggested that property rights perform a vital role in protecting the individual against the state in a society which places the highest value on material well-being. Reich, The New Property, 73 YAIE L.J. 733 (1964). If protecting the individual's material health is among society's major concerns in creating the abstraction of "property," then, where the basis for well-being is often represented by forms of government largess rather than something to which the individual can claim title, the procedural requirements by which the state removes this protection should attach to all "wealth" legitimately at an individual's command.

102 See, e.g., Greene v. McElroy, 360 U.S. 474 (1959).

${ }^{103}$ Laisne v. State Bd. of Optometry, 19 Cal. 2d 831, 835, 123 P.2d 457, 460 (1942); Cavassa v. Off, 206 Cal. 307, 314, 274 P. 523, 526 (1929) (pharmacy); Suckow v. Alderson, 182 Cal. 247, 187 p. 965 (1920) (medicine); Hewitt v. State Bd. of Medical Exam., 148 Cal. 590, 84 P. 39 (1906). But see Rosenblatt v. State Bd. of Pharmacy, 69 Cal. App. 2d 69, 74, 158 P.2d 199, 203 (1945), in which the court held that hicenses confer only personal privileges. The court rehed on the doctrine of constitutional prohibitions to upbold the Board's refusal to renew the license of an assistant pharmacist.

104 Fascination, Inc. v. Hoover, 39 Cal, 2d 260, 246 P.2d 656 (1952). 
ment. ${ }^{105}$ The right to a hearing was not contingent on the type of activity in which the hicensee engaged.

Utah has dealt a blow to the privilege-right distinction by a unique provision in its occupational regulation act which proclaims an "inherent right" to security of occupation, trade, or profession. ${ }^{100}$ The case law in other jurisdictions commonly contains statements similar to that embodied in the Utah security of occupation statute. ${ }^{107}$ These, too, reflect an awareness that a doctrine of right is replacing the doctrine of privilege.

The interest in occupational security has greatly affected the Supreme Court, which has responded by declaring that administrative agencies are not immune from constitutionally guaranteed procedural protections. In Greene v. McElroy, ${ }^{108}$ a government agency withdrew its security clearance for a private defense company's employce, making him useless to his employer. The Court overruled this action ${ }^{100}$ however, implying that the

$105 \mathrm{Id}$. at 270,246 P.2d at 662 . A lower appellate court had rejected the privilegeright distinction in the same terms twenty years earlier. Martin v. Board of Supervisors, 135 Cal. App. 96, 102, 26 P.2d 843, 845-46 (1933). The federal courts have not been overly concerned with the distinction. In one case involving a driver's license, in which the iden of privilege was invoked, Judge Magruder, speaking for the court, held the distinction to bo unimportant, since the 14th Aunendment's protection of "liberty" was the vital issue. Wall v. King, 206 F.2d 878, 882 (1st Cir. 1953). Though the court assumed the existence of a property right, the use of "liberty" to require procedural protection in administrative adjudication may have validity even where there is no property right.

106 The text of the statute is as follows:

The right to engage in any lawful profession, trade or occupation is an mherent right and such right shall not be impaired through state regulation unless the interests of the people of the state generally, as distinguished from those of a particular class, requires such regulation and state regulation is the most effective and equitable means of providing the necessary protection ....

UTAE CODE ANN. \$ 58-1-1.1 (1953). The Utah legislature's probable intent was to eliminate the doctrine of privilege to the extent it makes meaningless the "inberent right" and to create security of occupation and profession. The statute's vagueness does not detract from its position as a keystone of the occupational regulation act; as the first section of the act, this statement of general pohicy is presumably incorporated into every other section. Significantly, Utah is in the vanguard of states allowing administrative discovery. See text accompanying notes 247-58 supra.

107 In Bautista v. Jones, 25 Cal. 2d 746, 749, 155 P.2d 343, 345 (1944), the court stated: "The right to work, either in employment or independent business, is fundamental and, no doubt, enjoys the protection of the personal liberty guarantee of the Fourteentl Amendment to the federal Constitution, as well as the more specific provisions of our state Constitution." As long ago as 1915, the United States Supreme Court was able to say that "[i]t requires no argument to show that the right to work for a living in the common occupations of the community is of the very essence of the personal frecdom and opportunity that it was the purpose of the [fourteenth] Amendment to secure." Truax v. Raich, 239 U.S. 33,41 (1915).

108360 U.S. 474 (1959).

109 The Court held that the Defense Department had no delegated authority to fashion security programs whereby persons are deprived of their civilian employment without being given the right to effectively challenge the evidence and testimony. 360 U.S. at 502. The 
due process clause gives a person before an administrative agency the right to confront and cross-examine those whose word deprives him of his livelihood. The Court applied the right even thougl the government claimed national security interests were involved, ${ }^{110}$ thereby assimilating security clearances with occupational and professional licenses. In doing so, the Court referred to earlier decisions that the right to hold specific employment or to follow a chosen profession free from unreasonable government intereference came within the "liberty" and "property" concepts of the fifth amendment. ${ }^{111}$ What the Court had intimated in Greene v. McElroy, that an action whose result is to take away an individual's livelihood requires at least the right of confrontation and cross-examination, became a rule of law four years later. ${ }^{112}$

In Schware v. Board of Bar Examiners, ${ }^{113}$ the Court, speaking through Mr. Justice Black, dismissed the state's argument of privilege in a footnote. The state might call the permission to engage in the practice of law by whatever name it chose, but it was not within its power to exclude an individual from practice "except for valid reasons. Certainly the practice of law is not a matter of the State's grace." $" 114$

Secretary of Defense claimed two executive orders and the National Security and Armed Service Procurement Acts as delegating such authority. Id. at 500-04.

110 "Before we are asked to judge whether, in the context of security clearance cases, a person may be deprived of the right to follow his chosen profession without full hearings where accusers may be confronted, it must be made clear that the President or Congress, within their respective Constitutional powers, specifically has decided that the imposed procedures are necessary and warranted and has authorized their use. ... They inust be made explicitly not only to assure that individuals are not deprived of their cherished rights under procedures not actually authorized . . . but also because explicit action, especially in areas of doubtful constitutionality, requires careful and purposeful consideration ...." Id. at 507 .

111 Whether the earlier cases cited by the Court, id. at 492 , had gone so far as to require a hearing, confrontation, and cross-examination of those who would by their word deprive a person of his livelihood is debatable. The cases cited, with the exception of the Schware v. Board of Bar Exam., 353 U.S. 232 (1956), seem to stand for a more generalized right. See also Wall v. King, 206 F.2d 878 (1st Cir. 1953).

112 Willner v. Committee on Character and Fitness, 373 U.S. 96 (1963). The Court cited Greene as authority for the proposition that "procedural due process often requires confrontation and cross-examination of those whose word deprives a person of his livelihood." Id. at 103. Although the Court cited several state cases applying the same principle where admission to the bar was at issue, any notion that the opinion's significance extends only to the sui generis nature of bar proceedings is dispelled by the Court's repeating what it had earlier said in Schzware, that states could not exciude a person "from the practice of law or from any other occupation" in violation of due process. Whether the use of the word "often" in the Willner quote cited above has any independent significance is a question which must be left for future cases.

113353 U.S. 232 (1956).

114 Id. at 239 n.5.

In a recent lecture, Justice Fortas raised the broader question of the necessary procedural protections whenever the state's action is regarded as an exercise of grace-the 
Traditionally, the recipient of government largess has been entitled to certain procedural protections only if the gratuity was in the nature of property. However, the rule which seems to be evolving is that where a hicense or franchise action necessarily involves a determination of adjudicative facts, the use of differing nomenclature should make no difference as to required procedural protections. ${ }^{115}$ The Supreme Court, by emphasizing the right to fundamental due process where major consequences are involved, has helped shift the focus on the problem of government largess from privilege versus right to the nature of the sanction involved. ${ }^{116}$ The ultimate rule of law may well be that similar sanctions require similar protections, whether the proceeding begins in the agency or in a court.

\section{Discovery in Administrative Adjudication as a Constitutional Right}

It has been suggested above that agency action falls within the Constitution and that agencies behaving like courts must, like courts, observe certain constitutional precepts. Accordingly, those agencies which act like criminal courts, by initiating essentially accusatorial actions, must recognize the same constitutional protections as do criminal tribunals. Subsection (a) will therefore describe those agency actions which resemble criminal proceedings, while subsection (b) will analyze the extent to which a right to discovery is constitutionally compelled in crimmal proceedings.

(a) Similarity Between Agency Adjudication and Criminal Proceeding. -It is the purpose of this section to suggest that some agency action, par-

giving of bounty. Fortas, Equal Rights-For Whom?, 42 N.Y.U.L. Rev. 401 (1967). Justice Fortas addressed himself particularly to the developing welfare law, but what he said on that subject seems to have been only part of a more general discussion of all "hounty."

"Must the state see to it that the constitutional guarantees available to 'persons' are safeguarded in this process?" Id. at 411. His conclusion regarding the welfare recipient's right provides a possible answer: Although the state is entitled to provide reasonable standards for welfare, it does not follow that it thereby becomes entitled to treat the recipients of its bounty "as persons who have, in return for welfare payments, surrendered to the state's social workers their constitutional rights." Id. at 412.

115 Of great procedural significance is Hornsby v. Allen, 326 F.2d 605 (5th Cir. 1964), in which the petitioner was denied a liquor license without a hearing by the city of Atlanta. The respondent argued that because the sale of liquor is a privilege, the licensing authority had unreviewable discretion to grant or deny licenses. Id. at 609 . Determining licensing to be an adjudicative process, the court held the fundamental requirements of due process to be applicable. Chief Judge Tuttle, writing for the court in overruling a dismissal by the district court, announced that a complaint alleging a denial of a protected right, privilege, or immunity under color of state or local law was sufficient to require the fedcral court to entertain the action under the Civil Rights Act, 42 U.S.C. \& 1983 (1964). The effect of the decision may well be to render the privilege doctrine ineffectual, since one whose license is denied or revoked without a hearing and its incidents may get relief in the federal courts. 116 See, e.g., Greene v. McElroy, 360 U.S. 474, 508 (1959). 
ticularly that governing the granting, restricting, and revoking of licenses, is so "punitive" in nature as to resemble a criminal proceeding. In each case, the state initiates the proceedings; in each case, the state acts as both prosecutor and judge; in each case, the state makes adjudicative inquiry into the defendant's conduct; and in each case, the state's sanction stigmatizes the individual. Because of their similarity, therefore, state agencies and criminal courts may well be expected to operate within the same constitutional framework.

There is no agency which records the fate of those whose licenses were revoked or whose franchises were withdrawn. The consequences of such administrative actions are not, however, impossible to imagine. Admittedly, imprisonment is not a direct consequence of an agency decision to take away an individual's certificate. Moreover, loss of civil rights is not incidental to a finding against the respondent as may be the case with one found gmilty of a crime. ${ }^{117}$ And it is probable that a far greater percentage of these individuals find other gainful employment than is the case with convicted violators of the penal code. Whether these factors so differentiate the administrative from the criminal action as to merit a distinction is, however, questionable.

In a society which emphasizes productive and useful employment, and usually grants recognition and status according to the individual's employment, as well as the wealth he thereby accumulates, the loss of a license or franchise can be a catastrophic event. Not only does it represent the loss of livelihood, but it may also signify the contemporaneous inposition of public disrepute. ${ }^{118}$ In short, agency action may result in obliteration of everything coming under the heading of "life-style," which las taken the individual years to create for himself and his family. Sintilar consequences may follow a physical injury or business reverses, but the loss of a certificate to carry on a busmess is different in that the consequences incident to it flow from direct state action. Qualitative and quantitative conparisons between short periods of confinement under a criminal statute and the consequences which may follow administrative action are impossible, but what is significant to the individual is that both are sanctions which will greatly affect his present and future existence. This argues for the proposition that fairness demands that one burdened by certain types of administrative action receive as complete an opportunity to disprove the essential adjudicative fact as does a criminal defendant.

While recogmizing that agencies revoke licenses and franchises for in-

117 E.g., CaI. PeN. Code $\$ 2600$ (West 1956).

118 Some state statutes make provision for a "plea of guilty." E.g., ArA. CodE tit. 46, $\S 93$ (1958). 
dividual wrongdoing, courts have been reluctant to call such administrative sanctions "penal."119 Some of that restraint may flow from the reluctance to impose on administrative agencies all the constitutional adjuncts of a criminal proceeding, for it may be felt that such rigid adjuncts would divest admmistrative proceedings of their unique role. ${ }^{120}$ In California, for example, a substantial body of authority supports the proposition that an administrative sanction is neither "quasi-criminal" nor criminal. ${ }^{121}$

Nonetheless, as with the privilege-right distinction courts are beginning to suspect the traditional distinction between administrative sanctions on the one hand, and "penal" or "quasi-criminal" sanctions on the other. Instead, they look in each case to the sanction involved, rather than

110 The Supreme Court has used the phrase "civil administrative sanctions" to describe the penalty imposed by the agencies. Helvering v. Mitchell, 303 U.S. 391, 406 (1938). The Selective Service System may be somewhat of an exception to the reluctance to call adimnistrative sanctions "penal." When the Selective Service Regulations were amended, as of November 1, 1943, to provide for reclassification of delinquents to 1-A, Assistant Attorney General Tom Clark characterized the regulation as "an administrative penalty." Martin, Trial by Hershey: The Draft as Punishment, 206 TrE Nation 139, 141 (1968). Professor Martin notes that "[a]lthough the Selective Service now avoids language which would suggest it is using the draft to punish delinquents, in more candid monents it too has recognized this intent. A 1950 report on enforcement of the 1940 law, signed by General Hershey, spoke of the reclassification regulation as establishing an "administrative penalty." Id.

120 Many of the instances in which courts have held that the proceedings were not quasi-criminal have arisen when they have sought to upliold such fundanental principles of administrative procedure as the preponderance of evidence rule, e.g., Webster v. Board of Dental Exam., 17 Cal. App. 2d 534, 110 P.2d 992 (1941), and liberal evidence rules, e.g., Marlo v. State Bd. of Medical Exam., 112 Cal. App. 2d 276, 246 P.2d 69 (1952) (uncorroborated testimony of accomplice can support agency finding) ; Stuck v. Board of Medical Exam., 94 Cal. App. 2d 751, 211 P.2d 389 (1949) (disnissal of crimnial case of no effect in administrative proceeding); West Coast Home Inp. Co. v. Contractors' State Licensing Bd., 72 Cal. App. 2d 287, 164 P.2d 811 (1945) (self-mcrimination privilege does not obtain); Tapley v. Abbot, 111 Cal. App. 397, 295 P. 911 (1931) (amendnents allowed to conforn to proof in accordance with liberal rules of pleading). The courts could accomplish this goal only by rejecting the argunent that the proceedings were criminal in nature.

121 Webster v. Board of Dental Exam., 17 Cal. 2d 534, 110 P.2d 992 (1941); Beanion v. Departunent of Motor Velicles, 180 Cal. App. 2d 200, 4 Cal. Rptr. 396 (1960) (not penal); Furnisl v. Board of Medical Exam., 149 Cal. App. 2d 326, 308 P.2d 493 (1957) (not penal); Marlo v. State Bd. of Medical Exam., 112 Cal. App. 2d 276, 246 P.2d 69 (1959); Cornell v. Reilly, 127 Cal. App. 2d 178, 273 P.2d 572 (1954) (liquor) (not criminal in nature); Kendall v. Board of Osteo. Exam., 105 Cal. App. 2d 239, 233 P.2d 107 (1951) (not criminal in nature); Murrill v. State Bd. of Accountancy, 97 Cal. App. 2d 709, 218 P.2d 569 (1950); Stuck v. Board of Medical Exam., 94 Cal. App. 2d 751, 211 P.2d 389 (1949); West Coast Home Imp. Co. v. Contractors' State License Bd., 72 Cal. App. 2d 287, 164 P.2d 811 (1945) (proceedings not governed by criminal law theories on matters of evidence); Bold v. Board of Medical Exam., 135 Cal. App. 29, 26 P.2d 707 (1933) (not criminal in character); Tapley v. Abbot, 111 Cal. App. 397, 295 P. 911 (1931) (pliysician) (more closely akin to civil than to criminal proceedings); Lanterman v. Anderson, 36 Cal. App. 472, 172 P. 625 (1918) (physician). 
the nature of the proceeding, in deciding whether to impose procedural protections. ${ }^{122}$ In One 1958 Plymouth Sedan v. Pennsylvania, ${ }^{123}$ the Supreme Court ruled that a proceeding whereby the state seeks forfeiture of an automobile is quasi-criminal in character; if the basis for the action is a charge of criminal conduct, the exclusionary rule of $M a p p v$. Ohio ${ }^{124}$ is applicable. The Court, rather than looking only to the tribunal in which the proceeding was conducted, focused on a comparison of the sanctions which were available in the civil and criminal actions. Because the sanctions were not qualitatively different, ${ }^{125}$ the Court concluded that it would be anomalous to exclude the illegally obtained evidence in a criminal proceeding, while admitting it in the civil proceeding in which a determination that the respondent had violated the criminal law would be necessary. Courts have traditionally recognized forfeitures as quasi-criminal, ${ }^{128}$ but in view of the manner in which they have approached the problem of dealing witl differences between two types of adjudication, such traditional nomenclature might not be meaningful. At least in cases in which criminal conduct is the basis for withdrawing a certificate to carry on an enterprise or profession, ${ }^{127}$ the Court may deem it constitutionally necessary, for the

122 In a recent California case, the Corporation Commissioner named plaintiff pawnbroker as a criminal without formal accusation or hearing, took away his employer's license, and threatened loss of hicense to anyone employmg the plamtiff. Endler v. Schutzbank, 68 A.C. 160, 436 P.2d 297, 65 Cal. Rptr. 297 (1968). The accusation of criminal conduct did not follow a hearing on the issue, and defendant was denied a formal hearing subsequent to the accusation. In holding that an opportumity for administrative review does not constitute the sort of "remedy" which a party must exhaust before invoking the assistance of the courts, the California Supreme Court focused its attention on the sanction which the agency imposes in requiring procedural protections. Whenever governmental action based on a stigmatizing judgment injures an individual by inducing others not to deal with him, the court said, he may challenge in court the agency's refusal to accord him a full hearing. Any person whose freedom to pursue his profession is seriously restricted by an official action or course of conduct designed to discourage his employment may compel the government to afford him a hearing complying with the traditional requirements of due process. Fundamental fairness requires that an individual be permited to defend himself publicly agamst official charges, however informal, which threaten to stain his personal and professional future. Id. at 178, 436 P.2d at 309, 65 Cal. Rptr. at 309.

123380 U.S. 693 (1965). The case did not involve adıninistrative action, but the Court's determmation seems clearly to be applicable to all tribunals in which a forfeiture proceeding is conducted.

124367 U.S. 643 (1961). The $M a p p$ rule provided that matter obtained by law enforcement officials by means of an illegal search and seizure cannot be admitted in evidence in a state criminal prosecution, on the ground that it would constitute a violation of the fourth and fourteenth amendments.

125380 U.S. at 701 . In the criminal action, the maximum penalty was a $\$ 500$ fine. In the forfeiture proceeding, the petitioner was faced with the prospect of loss of a $\$ 1,000$ autounobile.

$126 \mathrm{Id}$. at 700.

127 In another recent case involving forfeiture of citizenship, the Supreme Court held that where the sanction which the agency imposes is "plainly punishment," a prior criminal 
purpose of determining applicable procedures to merge administrative and criminal rules. ${ }^{128}$

California's supreme court has taken a step towards such a merger by declaring in Shively $v$. Stewart that a disciplimary proceeding in which an agency can prohibit an individual from practicing his profession has "a punitive character." This was a major factor leading to the court's determination that rules of discovery were applicable to some types of administrative adjudication. ${ }^{130}$ At stake were the licenses of two physicians who had allegedly performed criminal abortions. Ignoring California authority for the proposition that administrative proceedings were not penal, ${ }^{131}$ the court looked to the sanction-loss of a physician's licenseto determine whether the proceeding was punitive. Although the Shively court recognized that petitioners were charged with criminal conduct, it implied that the vital factors in determining the availability of criminal discovery were the punitive nature of the action, the concentration of functions in the agency, and the state's resources. ${ }^{132}$ The fact that the wrongdoing was criminal, and the adjudication thereby involved a determination of the same issue as would be involved in a criminal trial where protections for the defendant would be more stringent, merely emphasizes a fortuity. The Cahifornia court has apparently deemphasized the necessity of a criminal charge as a prerequisite for requiring procedures favorable to defendants in what is officially a civil proceeding. ${ }^{133}$

(b) Constitutional Right to Discovery in Criminal Proceedings.-It has

trial with all its incidents is constitutionally required. Kennedy v. Mendoza-Martinez, 372 U.S. 144, 167 (1963). It does not seem that the grounds for administrative action must be a criminal act. See id. The difficult question which remains for future decisions is how the phrase "plainly punishment" is to be defined. The emphasis the court has placed on bvelihood in the Greene, Schware, and Willner cases, see notes 108-14 supra and accompanying text, indicates the potential for a broad interpretation of the phrase.

128 Assuming this were the outcome, it might still be possible for the state to rely on the cominon statutory provisions allowing an agency to revoke or suspend where the hoider of a permit is guilty of "unprofessional conduct." The state could thereby avoid the consequences of relying on a criminal act for a revocation.

12965 Cal. 2d 475, 480, 421 P.2d 65, 68, 55 Cal. Rptr. 217, 220 (1966).

139 For a discussion of the extent of discovery permissible under the Shively case, see notes 278-83 infra and accompanying text.

131 See cases cited note 121 supra. The court not only failed to cite a single one of the earber cases which had rejected claims of quasi-criminality, but it ignored also an early California case which had upheld the doctrine of quasi-criminality. See Messner v. Board of Dental Exam., 87 Cal. App. 199, 205, 262 P. 58, 60 (1929). Instead, its single citation of authority on the issue of the proceeding's punitive nature was an article by Professor Reich, in which he called for a new judicial treatment of forms of wealth created by government largess. Reich, The Nezw Property, 73 YaIE L.J. 733 (1964).

132 See Shively v. Stewart, 65 Cal. $2 \mathrm{~d}$ at $479-80,421$ P.2d at 68 , 55 Cal. Rptr. at 220.

133 But see The Supreme Court of California, 1966-1967, 55 Calif. L. Rev. 1059, 1070-71 (1967). 
been submitted in earlier sections that agencies, like courts, are governed by fundamental constitutional standards, that some agency adjudications closely resemble crimmal prosecutions, and that those adjudications should therefore afford the same constitutional protections accorded criminal defendants. The following discussion suggests that among the constitutional protections enjoyed by criminal defendants may be a right of discovery.

Rules of discovery in state criminal actions are far less liberal than in civil actions; in fact, a number of states have no criminal discovery procedures whatsoever. ${ }^{134}$ In recent years, however, there lias been a waning resistance in the states to the argument that some form of discovery is necessary to ensure the defendant a fair trial. ${ }^{135}$ The ancient fear that granting discovery "would subvert the whole system of criminal law"130 has subsided. At least in the scholarly arena the advocates of discovery have apparently waged a successful fight. ${ }^{137}$

The scope of discovery in criminal adjudication, however, is still limited. In general, it is restricted to certain kind of statements-usually

134 See Mendelsohn v. People, 143 Colo. 397, 353 P.2d 587 (1960); Walker v. People, 126 Colo. 135, 248 P.2d 287 (1952); Walker v. State, 215 Ga. 128, 109 S.E.2d 748 (1959); Arthur v. Commonwealth, 307 S.W.2d 182 (Ky. 1955); State ex rel. Robertson v. Steele, 117 Minn. 384, 135 N.W. 1128 (1912); Territory v. McFarlane, 7 N.M. 421, 37 Pac. 1111 (1894); State v. Sharp, 162 Ohio St. 173, 122 N.E.2d 684 (1954); State ex rel Byrne v. Circuit Court, 16 Wis. 2d 197, 114 N.W.2d 114 (1962).

135 Of ten states cited by one author in 1962 as having unequivocally denied a defendant a right to pretrial discovery, Krantz, Pretrial Discovery in Criminal Cases: A Necessity for Fair and Intpartial Justice, 42 NEB. L. REv. 127, 146 (1962), three have since changed their position. Compare Commonwealth v. Balliro, 209 N.E.2d 308, 315 (Mass. 1965) ("To say that a defendant has a right to present his defense and then to deprive him of the means of effectively exercising that right would reduce the guaranty to an idle gesture;" defendant must be allowed to interview prosecution witnesses held in custody), with Commonwealth v. Chapim, 333 Mass. 610, 132 N.E.2d 404 (1956) (defendant has no right to see a copy of his confession); compare TENN. Code ANN. § 40-2441 (Supp. 1967) with Ivey v. State, 207 Tenn. 438, 34 S.W.2d 907 (1960); compare TeX. CoDE Crnr. Proc. art. 39.14 (1966) with Dowling v. State, 167 Tex. Crim. 43, 317 S.W.2d 533 (1958). Froin 1957 to 1960, there were five state appellate decisions recognizing or ordering discovery in a criminal case for the first time. Fletcher, Pretrial Discovery in State Criminal Cases, 12 Star. L. Rev. 293, 297 (1960).

${ }^{136}$ Rex v. Holland, 4 Durn. \& E. 691, 692, 100 Eng. Rep. 1248, 1249 (K.B. 1792). Even this stern rule against discovery had its exceptions. When the crime charged was the sending of a threatening letter, the document which was the basis for the charge was discoverable. Rex v. Harrie, 6 Carr. \& Payne 105, 172 Eng. Rep. 1165 (1833). When the interests of justice required, a surgeon named by defendants was allowed to inspect the contents of a poisoned stomach-the corpus delicti. Regina v. Spry, 3 Cox Crim. Cas. 221 (1848).

137 The recent literature is overwhelmingly in favor. See, e.g., Brennan, Criminal Prosecution: Sporting Event or Quest for Truth, 1963 WASH. U.L.Q. 279; Everett, Discovery in Criminal Cases-In Search of a Standard, 1964 DUKE L.J. 477; Fletcher, Pretrial Discovery in State Criminal Cases, 12 Stan I. Rev. 293 (1960); Harvard Student Legislative Research Bureau, A State Statute to Liberalize Criminal Discovery, 4 HARv. J. LEgrs. 104 (1966). 
those of the defendant and, sometimes, witnesses-and real evidence. ${ }^{138}$ Few states have gone so far in extending discovery to criminal actions as has California. ${ }^{139}$ The California courts have put the burden on the state to show what state interest requires a denial of discovery. ${ }^{140}$ The California courts' rapid recent development of criminal discovery rules was undoubtedly a factor whicl weiglied heavily in the supreme court's decision in the Shively case to extend discovery to administrative proceedings. ${ }^{141}$

In addition to claims that discovery in criminal proceedings will lead to perjury and intimidation, ${ }^{142}$ that it is unfair to give discovery rights to the defendant without extending benefits to the prosecution to a similar degree, ${ }^{143}$ and that the defendant already "has every advantage,"144 sev-

138 See Fletcher, supra note 137 , at 297.

139 Some of the leading eases and the rules of discovery enunciated by the court follow in chronological order. People v. Riser, 47 Cal. 2d 566, 585, 586, 305 P.2d 1, 13 (1956), cert. denied, 353 U.S. 930 (1957) (discovery at trial; but court says "absent some governmental requirement [of privilege] . . . the state has no interest in denying the accuscd access to all evidence that can throw light on issues in the case."); Powell v. Superior Court, 48 Cal. 2d 704, 312 P.2d 698 (1957) (discretionary power of trial court to allow discovery of defendant's statement before trial); People v. Silberstein, 159 Cal. App. 2d 848, 323 P.2d 591 (1958) (pohice reports); De Losa v. Superior Court, 166 Cal. App. 2d 1, 332 P.2d 390 (1958) (names and addresses of prosecution witnesses); Pcople v. Carticr, 51 Cal. 2d 590, 335 P.2d 114 (1959) (so long as defendant alleges he cannot recall his own statements, he has a right to discovery; rule of Powell v. Silberstein, sulpra, thus becomes an absolute right); Pcople v. Bernard, 172 Cal. App. 2d 314, 341 P.2d 743 (1959) (scientific reports); Norton v. Superior Court, 173 Cal. App. $2 \mathrm{~d} 133,343$ P.2d 139 (1959) (photographs used in identifying defendant). The tenor of the decisions follows the policy first enunciated in the Riser case, supra, that there is no state interest which requires denial of access to helpful evidence. Civil discovery techniques such as depositions have not been required. Justice Traynor has written, however, that "[i]t is too early to say whether additional experience will disclose a need to provide for additional pretrial discovery from independent witnesses. It may develop that a defendant needs no more than the right to discover the identity of such witnesses and any statements they have made to the police and the right to obtain orders when necessary to prohibit the prosecution from instructing witnesses not to talk to defense counsel." Traynor, Ground Lost and Found in Criminal Discovery, 39 N.Y.U.L. Rev. 228, 245 (1964). This clearly leaves open the question of depositions. California has also, in a much discussed decision, allowed discovery by the prosecution of defendant's evidence supporting his affirmative defense. Jones v. Superior Court, 58 Cal. 2d 56, 372 P.2d 919 (1962); see Louisell, Criminal Discovery and Self-Incrimination: Roger Traynor Confronts the Dilensma, 53 CaLIF. L. Rev. 89 (1965). See generally Louisell, Criminal Discovery: Dilemma Real or Apparent?, 49 CALIF. L. REv. 56, 61 (1961). For helpful comment on the procedural aspects of criminal discovery in California, see Comment, Discovery in California Criminal Cases: Its Importance and its Pitfalls, 38 S. CAx. L. REv. 251 (1965).

${ }^{140}$ See People v. Riser, 47 Cal. 2d 566, 586, 305 P.2d 1, 13 (1956), cert. denied, 353 U.S. 930 (1957).

141 See Shively v. Stewart, 65 Cal. $2 d$ 475, 479, 421 P.2d 65, 68, 55 Cal. Rptr. 217, 220 (1966).

142 See opmion of Chief Justice Vanderbilt, writing for the court in State v. Tune, 13

N.J. 203, 210, 98 A.2d 881, 884 (1953) (Brennan, J., dissented).

143 See State v. Rhoads, 81 Ohio St. 397, 424-25, 91 N.E. 186, 192 (1910).

144 United States v. Garsson, 291 F. 646, 649 (S.D.N.Y. 1923) (L. Hand, J.). 
eral other typical arguments against criminal discovery are of the same nature as those against discovery in administrative adjudication. Some have claimed, for example, that discovery will enable the defendant to harass the opposition, ${ }^{145}$ and thereby impede the progress and just determination of the cause. Another justification some advance for denying discovery rights is the possibility of coerced revelation of confidential information. ${ }^{146}$ However, policy considerations favoring the defendant's interest in disclosure have counteracted these arguments. Justice Brennan has forcefully defined a criminal trial's purpose as the ascertainment of truth rather than a sporting match im which the side having the most "surprises" for the opposition is most hikely to succeed. ${ }^{147}$ Discovery, authors have argued, is necessary to balance the prosecutor's advantage in having behind him the state's resources. ${ }^{148}$ As to the potential for perjury, harassment, and intimidation, proponents of discovery say that such fears are exaggerated. ${ }^{149}$ Moreover, it is possible to secure the government's interest in protecting confidential information by using a balancing test similar to that used in civil actions..$^{150}$

Federal courts have required the prosecutor in certain circumstances to disclose evidence of an exculpatory nature to the defendant since the Supreme Court ruled in 1935 that a conviction which the government obtained by knowingly using perjured testimony and suppressing exculpatory evidence was without due process. ${ }^{151}$ But the criteria for determining the applicability of the rule have changed.

Courts have found new answers to such questions as whether particular evidence is of a sufficiently exculpatory character, whether nonaccessability of the evidence is a prerequisite, whether the undisclosed evidence

145 See State v. Tune, 13 N.J. 203, 210, 98 A.2d 881, 884 (1953).

146 See State ex rel. Mahoney v. Superior Court, 78 Ariz. 74, 275 P.2d 887 (1954); State ex rel. Regan v. Superior Court, 153 A.2d 403 (N.H. 1959).

147 Brennan, Criminal Prosecution: Sporting Event or Quest for Truth, 1963 WASH. U.L.Q. 279.

148 See Fletcher, Pretrial Discovery in State Criminal Cases, 12 STAN. L. Rev. 295, 30506 (1960); Goldstein, The State and Accused: Balance of Advantage in Criminal Proceedings, 69 YaLE L. J. 1149 (1960); Traynor, Ground Lost and Found in Criminal Discovery, 39 N.Y.U.L. REv. 228, 249-50 (1964). In support of the argument, the commentators note the prosecution can make use of the grand jury and has at its disposal trained investigators and analysts, in addition to the advantage of preparation while the evidence is "hot." It might be noted further, that there is an advantage mhermg to the prosecutorial role which no constitutional decision can erase-the prosecutor is the people's protector and the defender of the public laws. This is a vital advantage in gathering evidence.

149 See opmion of Justice Brennan, dissenting in State v. Tune, 13 N.J. 203, 227, 98 A.2d 881, 894 (1953). Cf. Sunderland, Scope and Method of Discovery Before Trial, 42 YALE L.J. 863, 867 (1933).

150 See notes 47-52 supra and accompanying text.

151 Mooney v. Holohan, 294 U.S. 103, 112 (1935) (per curiam). 
must have been clearly responsible for the decision for purposes of reversal, and whether disclosure at trial satisfies the requirement. ${ }^{162}$ They have held that there may be a denial of due process where the suppressed evidence is not ipso facto exculpatory, but relates only to sentencing, ${ }^{163}$ to the credibility of a witness, ${ }^{154}$ or to opinions of psychologists. ${ }^{165}$ In such circumstances, the nondisclosure "taints" the conviction. ${ }^{160}$ As to accessibility, several circuits have called irrelevant or "too speculative" the fact that a more able, diligent or fortunate counsel might possibly have come upon the evidence through his own efforts. ${ }^{157}$ Consequently, the prosecutor, for the sake of caution, must disclose all exculpatory material, whether he beheves the defense counsel is aware of it or not.

There has been a great deal of confusion among the courts of appeal as to the showing of prejudice resulting from the failure to disclose the evidence necessary before the disclosure rule operates to reverse a conviction, but it is now becoming increasingly clear that such evidence need not be of the type which would clearly have produced a different result. The cases emphasize materiahty, ${ }^{158}$ but the application of this standard in specific fact situations indicates that the circuits have come very close to requiring disclosure of evidence which is merely "helpful" or "useful" to the defense. ${ }^{159}$ Such a standard is as broad as that which determines the

152 For an analysis of the development of the disclosure rule up to 1964, see Comment, The Prosecutor's Constitutional Duty to Reveal Evidence to the Defendant, 74 YALE L.J. 136 (1964).

153 Brady v. Maryland, 373 U.S. 83 (1963).

154 Napue v. Illinois, 360 U.S. 264 (1959) (per curiam); Levin v. Katzenbach, 363 F.2d 287 (D.C. Cir. 1966).

165 Ashley v. Texas, 319 F.2d 80 (5th Cir.), cert. denied, 375 U.S. 931 (1963).

156 Napue v. Illinois, 360 U.S. 264, 269 (1959).

157 Levin v. Katzenbach, 363 F.2d 287 (D.C. Cir. 1966) (per curiam). In this case the exculpatory information was not in the exclusive possession of the government. The opinion cited as authority for its holding on the question of accessibility, cases in which the evidence was in the hands of the government. Judge Burger thought this distinction so significant as to warrant a different result. He suggested the majority's opinion was a "thinly disguised holding that defense counsel gave Appellant ineffective assistance" and vowed that in the future he would regard the case as "nothing more than that." Id. at 295. Prior decisions involving accessibility of evidence in the possession of the government are Barbee $v$. Warden, 331 F.2d 842 (4th Cir. 1964), and United States ex rel. Thompson v. Dye, 221 F.2d 763 (3d Cir.), cert. denied, 350 U.S. 875 (1955) (accessibility) too speculative a consideration to outweigh actual unfairness). A state case in which disclosure by the prosecution of accessible evidence was required is State v. Fowler, 101 Ariz. 561, 422 P.2d 125 (1967). The evidence was in the possession of the police.

168 See, e.g., Brady v. Maryland, 373 U.S. 83, 87 (1963); Ashley v. Texas, 319 F.2d 80, 85 (5th Cir.), cert. denied, 375 U.S. 931 (1963).

150 It has been suggested that only a standard of the evidence's usefulness to the defense is consistent with the rationale of the suppression cases. Therefore, the prosecutor must be required to reveal all relevant evidence since bis job is not to determine for the defense what is useful. Comment, The Prosecutor's Constitutional Duty to Reveal Evidence to the De. fendant, 74 YaLE L.J. 136, 148 (1964). A recent federal decision on the point is Ingram $v$. 
permissible scope of the discovery techniques in civil actions. If the standard of "helpfulness" is combined with a requirement of pretrial disclosure, these principles begin in substantive effect to merge with those of civil discovery. No court explicitly enunciated such a requirement of pretrial disclosure, however, until $1967 .^{160}$ In light of the rationale of the suppression cases-that because of the vast resources at the State's command, and irrespective of the good or bad faith of the prosecutor, suppression of evidence favorable to an accused violates due process-it was perhaps inevitable that disclosure would be constitutionally required at any stage of the proceedings in which prejudice to the defendant would otherwise occur. ${ }^{101}$

However, this requirement is not necessarily applicable to the federal law of criminal discovery. The courts have spoken of "disclosure" and "discovery" as two independent sets of legal principles, despite the fact that one might obtain similar kinds of evidence by both. ${ }^{102}$ Because the ultimate objective in requiring disclosure is to avoid an unfair trial for the accused, ${ }^{163}$ however, it seems evident that the courts would have to destroy any barrier which would deprive a defendant of a fair trial by creating a sharp division in time whereby disclosure would be denied those seeking it before trial and allowed those seeking it during trial. The right to disclosure of exculpatory evidence is an empty one if the defendant-due to the exigencies of the trial court's calendar-cannot make use of it early enough so as to enable him to uncover additional evidence or to prepare his case.

Peyton, 367 F.2d 933 (4th Cir. 1966). There the prosecution's chief witness was misnamed so that the defense was deprived of an opportunity to learn he was a convicted perjurer. The court first stated the requirement of prejudice to be "a substantial likelihood that [the evidence] would have affected the result if known at the trial." Id. at 936. The court went on, however, to define the meaning of "affect," as being whether the jury "might well have entertained a reasonable doubt." Id. at 937. Judge Bazelon, concurring in Ellis v. United States, 345 F.2d 961 (D.C. Cir. 1965), states the rule as to nondisclosure being a violation of due process to be whether the testimony of a witness would have been "favorable" to the defense, even if it would not directly contradict evidence offered by the government. Id. at 963 n.5. For additional cases, see Ashley v. Texas, 319 F.2d 80, 85 (5th Cir.), cert. denied, 375 U.S. 931 (1963) (such vital significance as to amount to denial of due process); Barbee v. Warden, 331 F.2d 842 (4th Cir. 1964) (reasonable possibility that the nondisclosure might have contributed to the conviction).

100 The closest a court had come to deciaring such a principle was in Ashley v. Texas, 319 F.2d 80 (5th Cir.), cert. denied, 375 U.S. 931 (1963). Judge Tuttle noted the harn caused the defendant in planning and conducting his defense by the nondisclosure of two psychologists' report to the prosecutor that defendant was insane but made no mention of a requirement to disclose evidence before trial. Id. at 85 .

101 See Comment, supra note 159, at 145.

162 Compare, e.g., Ashley v. Texas, 319 F.2d 80 (5th Cir.), cert. denied, 375 U.S. 931 (1963), with FeD. R. CRnMr. P. 16(a).

163 See Brady v. Maryland, 373 U.S. 83, 87 (1963). 
Viewing discovery as an official disclosure system, no one can doubt that what the defendant seeks through discovery techniques is exculpatory evidence. Yet, the courts have not usually spoken of criminal discovery in constitutional terms. ${ }^{164}$ In 1951, the Supreme Court said that although it may be the "better practice" to allow inspection of a defendant's statement, there was usually no constitutional requirement to do so. ${ }^{165}$ Sixteen years later, when the question of pretrial access to evidence as a constitutional right arose in federal district court in United States v. Gleason, ${ }^{166}$ that court reached a different result. The difference is explicable as a consequence of Gleason's treatment of disclosure and discovery as related rules. What was constitutionally required by the disclosure cases overlapped with the federal discovery rules. The district court's opinion did not, of course, seek to overrule the Supreme Court but relied instead on Brady v. Maryland, ${ }^{167}$ the leading recent Supreme Court case on the constitutional requirements of disclosure and a later concurring opinion of Justice Fortas. ${ }^{168}$ In effect, the court created a pretrial discovery system whereby the judge has power to determine what is to be passed on to the defendant from the prosecutor.

In Gleason one of the defendants moved, under Brady, for disclosure "of any exculpatory evidence the government might have." The court first reject any right of the defendant to discover materials of which he was actually aware and which were readily accessible to him on the grounds that the defendant had not met the prerequisite of showing suppression. ${ }^{169}$ But in the remainder of the opinion, the court noted that the disclosure rule entitles the defendant to matters which are peculiarly within the knowledge and control of the government and considered the problem which the "not unreasonable" demand for disclosure of whatever there might be in the way of exculpatory evidence presented. It determined that the prosecution need not dehver to the defendant everything embraced in his demand; ${ }^{170}$ however, other instances would arise where the government had in its possession concrete evidence of a nature requiring pretrial disclosure "to allow for full exploration and exploitation

164 See Cicenia v. Lagay, 357 U.S. 504, 510-11 (1958); Leland v. Oregon, 343 U.S. 790, 801-02 (1952).

105 Leland v. Oregon, 343 U.S. 790, 801 (1951). Chief Justice Traynor has written that there is "probably no constitutional right to pretrial discovery." He implies, however, that there might be a constitutional question if no continuances were granted, thus precluding in some instances the possibility of the defendant being enabled to make effective use of the evidence. Traynor, Ground Lost and Found in Criminal Discovery, 39 N.Y.U.L. REv. 228, 242 n.77 (1964).

168265 F. Supp. 880 (S.D.N.X. 1967).

167373 U.S. 83 (1963).

168 Giles v. Maryland, 386 U.S. 73, 98 (1967).

169 See 265 F. Supp. at 884.

$170 I d$. 
by the defense."171 The court rejected as dangerous the possibility of having the prosecutor make timely disclosures or risk the prospect of ultimate reversal. It chose instead, despite the burdens on the court and prosecution, to conduct in camera proceedings. ${ }^{172}$

Although the court disclaimed any intention to define a standard for determining what kinds of evidence require disclosure, it nevertheless used "helpfulness" to the defendant as a guide in ruling on his motion. ${ }^{173}$ Of even greater significance, the court faced directly the difficult problem raised by the existence and recent modification by the Supreme Court's Advisory Committee of the Federal Rules of Criminal Procedure: Are requirements of the Federal Rules, promulgated by the Supreme Court, coincident with the constitutional requirements of disclosure? The court concluded that the Brady case "has the Constitution as its source, and the dimensions of due process are not limited or fully defined by the Rules of Criminal Procedure."174 As the court applied it, the effect of this principle is to make the Rules totally subordinate to the disclosure requirements. For instance, after the court had determined that certain statements in the government's possession might be helpful to the defendant, the prosecution, in response to the court's inquiry, registered its objection on the ground that the government is injured "anytime discovery of material is ordered in derogation of the Federal Rules."175 The court, noting it "had not found enlightenment in these pronouncements," dismissed the argument without discussion. ${ }^{176}$

The court apparently rehed heavily on Justice Fortas' concurring opinion in Giles v. Maryland ${ }^{177}$ in which he stated the distinction between the Federal Rules and the constitutional requirements as follows:

The newly amended Rule 16 of the Federal Rules of Criminal Procedure has little to do with [the question of disclosure]. On its face, the Rule is directed to the relatively limited problem of pretrial discovery and inspection in the federal courts . . . [I]t does not purport to exhaust the prosecution's duty. . . . My point relates not to the defendant's discovery of the prosecution's case for purposes of

171 Id. at 885 .

172 Id. The court here decided that a codefendant's statements need not be disclosed prior to trial, since there was a strong possibility that the codefendant would ultimately be a witness for the government. The defendant had a "vivid awareness" of the contents of the stateinent and was unable to advance any other reason for setting aside the Jencks rule. $I d$. at 887 . For a discussion of the Jencks rule, see note 20 supra.

173 See id. at 886 .

174 Id. at 884 .

175 Id. at 886 .

176 Id. One month before the Gleason case, a federal district court in Indiana, relying on the Federal Rules as determinative of the question, had come to a contrary decision when faced with the same question as confronted the court in Gleason. See United States v. Westmoreland, 41 F.R.D. 419 (1967).

177386 U.S. 66, 96 (1967). 
preparation or avoidance of surprise . . . but with the State's constitutional duty, as I see it, voluntarily to disclose material in its exclusive possession which is exonerative or helpful to the defense $\ldots . .^{178}$

Justice Harlan predicted in his dissenting opinion that Justice Fortas' suggested standard "must inevitably result in the imposition upon the States through the Constitution of broad discovery rules. These rules would entirely alter the character and balance of our present systems of criminal justice."

(c) Summary.-Some proponents of administrative discovery have argued by analogy to civil adjudication that agencies should be governed by rules patterned on the Federal Rules of Civil Procedure. ${ }^{180}$ It could also be argued by analogy to criminal prosecutions that certain agency adjudications should be governed by the Federal Rules of Criminal Procedure. This comment has suggested that because discovery may be constitutionally compelled in criminal proceedings independently of the Federal Rules of Criminal Procedure, it may be constitutionally compelled in analogous agency adjudications.

To sustain the criminal law analogy, it is necessary to show that certain administrative proceedings are "quasi-criminal" or "penal." Eventually, courts may view the "quasi-criminal" term as a vehicle for selectively imposing those procedural rights essential to a fair administrative hearing. ${ }^{181}$ The Cahfornia supreme court seems to have applied the term

$178 \mathrm{Id}$. at 101-02.

179 Id. at 117. Justice Harlan's statements were actually addressed to Justice Fortas' original concurring opinion in which the latter had defined the state's constitutional obligation in this area as that of seeing that, "so far as possible, truth emerges. . . . No respectable interest of the State is served by its concealment of information which is material, generously conceived, to the case, including all possible defenses." Id. at 109. Justice Fortas' statement quoted in the text appears in an addendum to his concurring opimion, which was a response to Justice Harlan's criticisms.

Two months later Justice Fortas, writing for the Court in an unrelated case, suggested by implication that there might be a constitutional requirement of allowing discovery of the defendant's statements. Clewis v. Texas, 386 U.S. 707, 712 n.8 (1967). He refrained from reaching that question, however. Significantly, Justice Fortas cited Cicenia v. Lagay, 357 U.S. 504 (1958), and Leland v. Oregon, 343 U.S. 790 (1952), both of which are discussed at notes 164-65 supra and accompanying text, as support for the proposition that the Court had previously suggested a denial of discovery might in some circumstances amount to a denial of due process. These cases have usually been cited as standing for the primciple that discovery is not a constitutional requirement. See, e.g., State v. Johnson, 28 N.J. 133, 136-37, 145 A.2d 313, 315 (1958). In the Cicenia case, the Court noted that prejudice to a defendant might require a different result but held that the "discretionary refusal" to permit inspeetion did not offend the Fourteenth Amendment. Inspection was merely the "betier practice." 357 U.S. at 511 .

180 See, e.g., Berger, Discovery in Administrative Proceedings: Why Agencies Should Catch up with the Courts, 46 A.B.A.J. 74 (1960); Comment, Discovery Prior to Administrative Adjudications-A Statutory Proposal, 52 CaLF. L. Rev. 823 (1964).

181 It is conceivable that courts may use the term "quasi-criminal" or "punitive" to signai the applicability of certain procedural rights which are essential to a fair administra- 
"punitive" in this fashion in holding that a respondent was entitled to discovery where the agency sought to revoke his license to practice medicme. ${ }^{182}$ The court, then, in effect believed the sanction was criminal enough to require discovery.

It is important to note that if discovery comes to the agencies as a constitutional requirement, rather than as a matter of legislative policy, it will be limited in its applicability. As a constitutional requirement, it would be based on the analogy between some, but not all, administrative proceedings and criminal cases. Such a base is not sufficient to support discovery in proceedings which do not involve adjudicative facts or the imposition of punitive sanctions.

Discovery may arrive in the agencies by means of an additional, independent effect. If the disclosure requirements merge with the rules of criminal discovery, thereby extending broad discovery rights to criminal actions, it is conceivable that the impetus given to rules of discovery as a general procedure and the resulting isolation of the agencies in resisting discovery will create a spillover effect in the agencies; such an effect is not, however, constitutionally compelled.

II

DISCOVERY IN IICENSE REVOCATIONS ANDSUSPENSIONS:

STATE OF THE LAW

\section{A. Regulation of Occupations and Professions}

Licensing agencies typically regulate broad and varied activities, from the practice of medicine, including most of the specializations, ${ }^{183}$ to dry cleaners and shorthand reporters. ${ }^{184}$ The impetus for such regulation usually comes from the occupational group itself, ${ }^{185}$ but the legislatures sometimes are able to resist pressure groups' demands for an administrative board. ${ }^{188}$ Statutory provisions providing for revocations or suspen-

tive hearing, much as the Supreme Court uses the fourteenth amendment's due process clause to signal constitutionally required protections. Whether an incorporation, selective incorporation, incorporation "plus", or "fundamental fairness" test is used in applying the fourteenth amendment's due process clause to the states, "due process" is merely a term signifying a cluster of procedural rights. The content of the cluster may change with individual justices, but the representative nature of the phrase "due process" remains constant.

182 Shively v. Stewart, 65 Cal. 2d 475, 480, 421 P.2d 65, 68, 55 Cal. Rptr. 217, 220 (1966).

183 See, e.g., Cax. Bus. \& Prof. Code \$\$ 2000-2694 (West 1962) (the jurisdiction of the Board of Medical Examiners covers physicians, chiropodists, surgeons, midwives, registered physical therapists, physical therapists, and registered dispensing opticians).

184 E.g., CaI. Gov'T Code \$ 11501(b) (West 1966).

185 Monaghan, The Constitution and Occupational Licensing in Massachusetts, 41 Boston U.L. REv. 157, 166-69 (1961). Mr. Monaghan traces the interest of the occupational group in being regulated to two sources: the desire for economic security and the quest for social recognition. Id. at 167 .

186 In California, auto mechanics, parking lot operators, maintenance gardeners, plumb- 
sions usually explicitly set forth several grounds for such agency actionsuch as gross negligence or conviction of a crime involving moral turpitude. But the specificity may often be preempted by a very vague authority to revoke licenses where the practitioner is guilty of "unprofessional conduct"187 or "gross immorality."1.88 The Pennsylvania statute regulating physicians is typical. After specifying certain wrongdoing with particularity, the statute additionally provides for revocation or suspension "for any other cause . . . at such time as it shall appear to the board to be just and proper to do so."189

Enforcement provisions for the regulatory acts vary with the states. Where an APA covers state agencies, the provisions pertaining to procedural rules for revocation and suspension ${ }^{190}$ cases are usually contained in the adjudication or "contested case" sections. Two states have special licensing acts whose procedures the legislatures created with the professional and occupational licensee almost exclusively in mind. ${ }^{101}$ Less than one-half of the states have such a general statute defining the licensee's procedural rights, however; in the other states, to find the agency procedures a lawyer must look to the statute delegating authority to the agency as well as to the agency's published rules and regulations. Even in states having an APA, specific ${ }^{102}$ or implied ${ }^{103}$ exclusions of certain agencies often limit their scope. In Indiana, for example, the APA does not cover the state colleges and universities, penal institutions, the board hearing workmen's conpensation cases, the alcoholic beverage commission, the $\operatorname{tax}$ board, or the Public Service Commission. ${ }^{194}$ Hence, pro-

ers, small boat builders, and masseuses all attempted to obtain regulation in one recent year but were unsuccessful. Note, Entrance and Disciplinary Requirements for Occupational Licenses in California, 14 Stan. L. Rev. 533, 537 (1962).

187 E.g., CAL. Bus. \& Prof. CoDE $\S 3090$ (West 1962).

188 E.g., id. \& 1680(8).

189 Pa. STat. ANrv. tit. 63, $\S 410$ (Supp. 1967). Some authors have criticized the application of standards of morality to occupations and professions not imvolving a high degree of confidential relations between the practitioner and his client. They have said such requirements are irrelevant, and result in frustrating society's interest in free competition, rehabilitation, and efficient allocations of its resources. See, e.g., Note, Entrance and Disciplinary Requirements for Occupational Licenses in California, 14 STAN. L. REv. 533, 538-39, 547-48 (1962).

190 Suspension involves only a temporary halt to the business of the licensec. For this reason, courts may uphold summary procedures prior to formal hearings in suspension cases. See State Bd. of Medical Exam. v. Weiner, 68 N.J. Super. 468, 172 A.2d 661 (1961).

191 Colo. Rev. Stat. § 3-16-1(1963); N.M. Stat. AnN. § 67-26 (1961).

192 See, e.g., IND. ANN. STAT. \$ 63-3002 (1961).

193 See, e.g., CaL. Gov't CODE $\$ \S 11500-01$ (West 1966). The cited statute does not include local agencies, and they have been held to be beyond the scope of the APA. Allen v. Humboldt County Bd. of Supervisors, 220 Cal. App. 2d 877, 34 Cal. Rptr. 232 (1963). Also excluded is the Public Utilities Commission. See Cax. Gov't Code \$§ 11500-01 (West 1966). 194 IND. ANN. Stat. \& 63-3002 (1961). 
cedural protections for licensees may be substantially less stringent than the APA's minimum, even in states having such acts.

The state regulatory acts usually give the hicensing agencies power to subpoena persons and evidence as a necessary incident to its power to investigate. ${ }^{195}$ The state agencies, however, probably do not need compulsory process as much as federal agencies do: ${ }^{\mathbf{1 9 6}}$ Because state agencies operate in a far more informal environment and deal with individuals who are often unable to hire expensive counsel, ${ }^{197}$ whatever information the state agencies seek is usually readily available. In dealing with an individual whose livelihood depends largely upon the certificate the state has issued to him the power of the agency manifests itself with inherently coercive force. The potentiality of revocation is ordinarily sufficient to bring forth the desired information. ${ }^{198}$

\section{B. Possibilities for Obtaining Information Prior to the Hearing}

The majority of states ${ }^{199}$ have no statutes which authorize any discovery in agency license adjudication. ${ }^{200} \mathrm{~A}$ small but growing minority of states, however, do have statutory provisions which either explicitly ${ }^{201}$ or by necessary implication ${ }^{202}$ grant discovery rights to the licensee.

It is arguable that in most states the statutory provisions regarding

195 See, e.g., Ind. ANn. Stat. § 63-3007 (1961).

196 See 1 F. Cooper, State Administratrve LaW 294 (1965).

197 See, e.g., CaL. Gov't Code § 11501(b) (West 1966).

198 A recent study of political attitudes in the United States, United Kingdom, Germany, Italy, and Mexico indicates the extent to which individuals feel powerless when confronted by administrative action. See G. Alarond \& S. Verba, Tre Civic Culture (Little, Brown ed. 1965). Large majorities of Americans see their local governments as having some impact on their lives. Id. at 47. Eighty-three per cent believe they would be given equal treatment by the bureaucracy as to a question they had to take to a governmental office. But while $66 \%$ believe "they can do something about an unjust law" both on the national and local levels, only $37 \%$ expect serious consideration from administrative officials. Id. at 173 .

199 The following survey of license adjudication is based on a study of state APA's and statutes creating the agencies. Where a state had an APA or similar act covering adjudication, which was at least comparable in thoroughness with the Model Acts, primary reliance was placed on it. Where there was no APA or similar act, the statutes relating to licenses for the sale of liquor and licenses for the practice of medicine were consulted. The procedures provided for revocation or suspension of these two licenses are thought to be indicative of license revocation or suspension procedures in general: The liquor license represents perhaps the weakest of the privileges, while the medical license approaches a vested right.

200 Several states provide for depositions by the agency. E.g., Vr. Star. ANN. tit. 7, $\S 236$ (1958).

Where only the agency has such a right, this is not in any sense "discovery," but only part of the agency's general investigative powers. It is doubtful whether such a deposition power adds anything more than the provision commonly found in the states by which an agency is empowered to issue subpoenas in order "to take testimony." E.g., TEx. Crv. Stat. ANN. § 4509 (1966).

201 E.g., Wyo. Stat. ANr. § 9-276.19 to 33 (Supp. 1967).

202 See, e.g., W. VA. CODE ANN. § 29A-5-1(c) (1966). 
agency procedures allow for prehearing discovery. An agency seeking such a result could create discovery rights pursuant to its delegated power to make appropriate procedural rules. In licensing adjudications, however, the agency is an adversary and unlikely to afford discovery to its opponents; therefore, the discovery debate may have to be decided by the courts.

The purpose of this section is to examine the state of the law regarding a licensee's ability to obtain information which he needs to prepare for his hearing. The first subsection will survey, the potentialities of various notice requirements as discovery devices. Provisions for depositions and other techniques of discovery will be examined next. The last subsection will analyze miscellaneous statutory provisions which may allow discovery.

\section{Notice Provisions}

At the commencement of the adjudication, the licensee may be entitled to a minimal amount of discovery ${ }^{203}$ by virtue of the agency's having to give him notice of the charges. The notice provisions usually require the agency to give some indication of the basic issues. ${ }^{204}$ The Model State APA provides simply for a statement of "the issues involved." "The Revised Model State APA requires "a short and plain statement of the matters asserted."206 Because these provisions do no more than make the hicensee generally aware of the pending action and inform him only in the broadest terms of the basic issues, it is questionable whether the Model Acts are helpful to the licensee. Although the Model APA gives each agency power to adopt "appropriate rules" for notice, apparently the drafters did not intend thereby to enlarge the statutory notice provisions. ${ }^{207}$

Several states have given purpose to the notice provisions by adding to the APA a statement of objectives. For example, California's notice provision demands a written statement of charges "to the end that the respondent will be able to prepare his defense."208 Massachusetts makes the relationship between notice and preparation even clearer by requiring notice which affords "reasonable opportunity to prepare and present evi-

203 "Discovery," in this sense, is used to signify all means of fact ascertainment, rather than the devices provided by the Federal Rules of Civil Procedure and many state statutes.

204 E.g., CAL. Gov'r CODE $\$ 11503$ (West 1966).

205 Moder State APA \& 8, 9C U.L.A. (1957).

206 Revised Moder State APA § 9(b) (4), 9C U.I.A. (Supp. 1967). Cahifornia uses the phrase "ordinary and concise language" as a requirement for giving notice of the charges. CAL. Gov'r CoDe $§ 11503$ (West 1966).

207 The "appropriate rules" provision was omitted in the Revised Act. The Commissioner's Note to $\S 9,9$ C U.I.A. (Supp. 1967), at 151, states that the section "enlarges considerably upon the corresponding provisions of the original Model Act."

208 CaL. Gov'r Code $\S 11503$ (West 1966). 
dence and argument."209 However, it is doubtful whether even such explicit requirements succeed in granting the licensee any discovery rights. ${ }^{210}$ In the Massachusetts statute, for example, the words "to prepare" seem only to require the notice to be sufficient to enable the licensee to proceed, independently of any aid the agency could give him, in his own investigations. This falls far short of gaining access to information already im the agency's possession. An attorney might make a stronger argument for discovery where a statute uses the term prepare in the context of a hearing ${ }^{211}$ rather than in the context of the notice's sufficiency.

Two states liave gone mucli further towards "discovery by notice." The legislatures of New Mexico and North Carolina have apparently concluded that merely stating the issues does not adequately give the licensee an adequate opportunity to meet the accusations against him and lave therefore required the notice to indicate "the general nature of the evidence."212 These are the only statutes addressed to "evidence" rather than "issues"213 or "matters asserted."

200 Mass. Gen. Laws Ann. ch. 30A, § 11(1) (1966).

210 For a discussion of the inadequacies of notice, see Discovery Proceedinngs, supra note 10, at 50. See particularly the remarks of Assemblyman Z'berg:

[T]he upshot of the whole [case] isn't going to be very much except the pleading does call for the revocation of a man's hicense because that's what they all do. ... Well, you don't know what might or might not happen so you've got to defend that to the utmost if you are a real estate broker or if you have a bar license, or whatever it might be. ... [T]here are thousands and thousands of dollars involved -it's a man's livelihood .... [Y] ou don't know what's in that file of the counsel, or what his motives or desires are, what kind of record he's trying to make for himself, or whether the investigative officer just had it in for some particular fellow, and the case is not being tried with everything out in the open. So I would think [the file containing statements of witnesses and any documentary evidence or documents] ought to be made available ... whether they are introduced into evidence or not. . . . There might be some evidence there which is very beneficial to his side and I haven't found very many counsel for agencies yet who go out of their way to help lose their case by offering evidence to the attorney on the other side which is going to help him and luurt his case,

Id. at 88-89. See also id. at 9 (remarks of Mr. Duncan).

211 For discussion of such a statute, see note 298 infra and accompanying text.

212 N.M. Stat. AnN. § 67-26-4(2) (1961); N.C. GeN. Stat. § 150-11(b)(2) (1964). Both are recent enactments. New York specifically prohibits such broad notice in its medical regulation act. "All such notices of charges shall contain a plain and concise statement of the material facts . . . but not the evidence by which the charges are to be proved." N.X. Educ. LAW § 6515(4) (McKinney 1953).

Although Arkansas enacted a discovery provision for administrative adjudication in 1967, No. 434, $\$ 9(c)(5),[1967]$ Ark. Acts-, the legislature repealed in the same year a notice provision requiring the agencies to indicate the "general nature of the evidence," No. 103, $\S 3(\mathrm{~b})(2)$, [1963] Ark. Acts 208. A new provision requires only that the notice contain a "short and plain statement of the matters of fact and law asserted." ARK. STAT. ANN. \$ 5-708(b) (3) (Supp. 1967).

213 E.g., HaWaII Rev. LaWs § 6c-9(b) (4) (Supp. 1965).

214 E.g., Ga. Code ANN. \& 3A-114(1) (D) (Supp. 1967). 


\section{Depositions and Other Discovery Devices}

For the most part, what little administrative discovery exists among the states is in the form of provisions for depositions. This is probably explained by historical circumstances described below. ${ }^{215}$ Fortunately for respondents, depositions are perhaps the most powerful of all discovery devices. Unlike interrogatories, which have been limited to adverse parties, ${ }^{216}$ a respondent, at least under the Federal Rules, can take depositions of "any person," including a nonparty. ${ }^{217}$

The only state having a comprehensive discovery scheme is Wyoming, whose legislature enacted an $\mathrm{APA}^{218}$ in $1965 .^{210}$ The act covers all nonrevenue license adjudications in which statutes require a hearing. ${ }^{220}$ Both parties have the right to use all of the discovery devices which are available in civil actions: Depositions, interrogatories served upon an adverse party, inspection and copying, physical and mental examinations, and demands for admission. ${ }^{221}$ The only civil discovery provisions excluded from the act are those dealing with perpetuation of testimony ${ }^{222}$ and the sanction powers. Sanction powers allow a court to hold in contempt one refusing to be sworn or to answer questions ${ }^{223}$ and to arrest a party disobeying any discovery order other than one ordering him to submit to a mental or plyysical examination. ${ }^{224}$

Contempt power remains with the courts, who may act upon the agency's application. ${ }^{225}$ All other sanctions, including striking pleadings, dismissing the action, rendering a default judgnent, and taking as established in accordance with the adverse party's clain those inatters regarding which lhe asked his questions, are available. ${ }^{228}$ Critics may find the preservation of these sanctions the most questionable aspect of the discovery provisions. Some inay argue that when an agency proceeds against an individual whose profession or occupation siguificantly affects the public interest, it seriously endangers the public welfare to take as established facts the allegations of the one accused of wrongdoing. The agency's refusal to make discovery may be some evidence of the weakness of its case, but it is not conclusive. Agency officials might, for in-

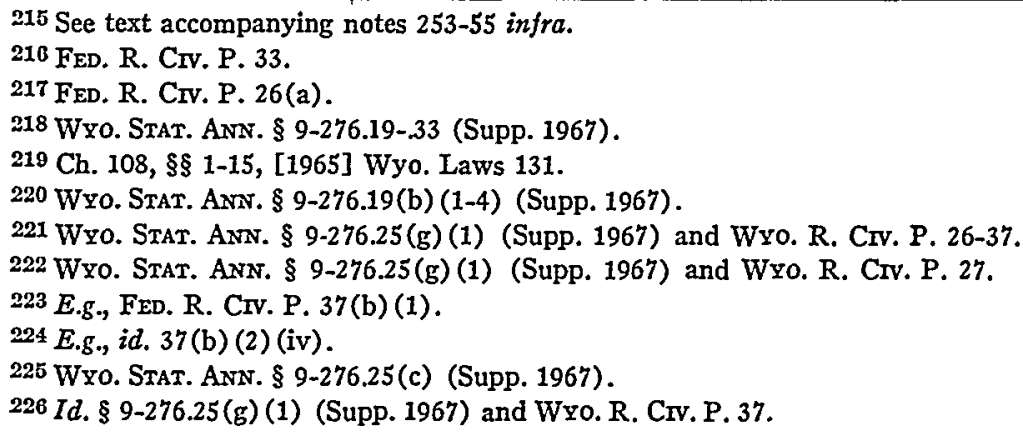


stance, refuse to make discovery because they believe it absolutely essential to protect information they, but not the presiding officer, deem to be confidential. To allow a possibly dangerous practitioner to menace the community in such circumstances seems to overemphasize the discovery rules at the expense of the public policy which alone justifies them. A better procedure might be to rely for enforcement solely on the contempt power of the courts to compel discovery. In this way, the fact of agency intransigence will not automatically result in authorized practice by incompetents. The courts might use the sanctions noted above as a last resort in order to protect the licensee facing an agency which absolutely refuses to allow discovery.

Although it was superfluous, since the agency is a party to the adjudication, the Wyoming legislature included a provision emphasizing that the agency was subject to the discovery provisions. ${ }^{227}$ To prevent harassment and the interruption of administration, the respondent cannot force members of the agency to be deponents ${ }^{228}$ however, the statute clearly does not except agency officers and eniployees from the normal class of persons subject to depositions. ${ }^{229}$ Rules of privilege apply as at law. ${ }^{230}$

Besides Wyoming, Arkansas ${ }^{231}$ and Colorado ${ }^{232}$ are the only states whose administrative procedure statutes mention "discovery." Arkansas" legislature enacted a provision in $1967^{233}$ giving the presiding officer in licensing adjudications ${ }^{234}$ power "to permit discovery by deposition or otherwise." 235 The statute presumably incorporates at least all the discovery devices which the Federal Rules of Civil Procedure provide, and conceivably any others which the liearing officer miglit create. Unlike the Wyoming scheme, however, the respondent is not entitled to discovery as of right, but must depend on the discretion of the presiding officer. ${ }^{236}$

With the exception of a provision authorizing the hearing officer to "dispose of motions relating to the discovery and production of relevant documents and things for inspection, copying or photographing,"

227 Wyo. Stat. ANn. \$ 9-276.25(h) (Supp. 1967).

228 Id.

$229 I d$.

$230 I d$.

231 ARK. Stat. ANN. § 5-709(c) (5) (Supp. 1967).

232 Colo. Rev. Stat. ANN. \$ 3-16-4(4) (1963).

233 No. 434, § 9(c) (5), [1967] Ark. Acts -.

234 The provision applies to "every case of adjudication," Ark. Stat. ANw. § 5-709

(Supp. 1967), which includes all licensing proceedings. Id. §5-701(d), (e).

235 Id. \& 5-709(c) (5) (Supp. 1967).

230 See id.

237 Colo. Rev. Stat. ANn. \$ 3-16-4(4) (1963).

In view of procedures for "copying," as well as the use of the word "discovery," it is 
Colorado legislature has given no directives for discovery procedure. The presiding officer has power to direct the parties to appear for a prehearing conference, ${ }^{238}$ and it is presumably at this conference that discovery motions are made; however, the statute does not refer to depositions as a discovery device. In most other states where discovery-though not mentioned as such-is available, it is only depositions, rather than documentary evidence and "things" which are discoverable. ${ }^{230}$ Thus, Colorado, Arkansas, and Wyoming appear to be the only states allowing inspection and copying in license adjudications. ${ }^{240}$

In West Virginia, ${ }^{241}$ North Dakota, ${ }^{242}$ and Utah, ${ }^{243}$ statutory provisions clearly make discovery by depositions available in revocation or suspension proceedings, although the statutes do not speak of "discovery." West Virginia's APA provides that "evidentiary clepositions may be taken and read [in administrative proceedings] as in civil actions in the circuit courts of this state."244 The state has broad civil discovery rules, patterned after the Federal Rules, ${ }^{245}$ which govern the circuit courts. ${ }^{246}$

Utah's Registration Act covering license procedures for thirty professions and occupations provides for depositions "in the same manner and on the same grounds" provided for actions at law. ${ }^{247}$ Utah's rules of discovery follow the Federal Rules. ${ }^{248}$ North Dakota's APA provides for depositions "in any proceeding before an agency ... in the same manner" as in civil actions; ${ }^{249}$ North Dakota also has broad civil discovery rules. ${ }^{260}$

clear that pretrial discovery and not merely disclosure at the trial was contemplated by the legislature. It is possible however that the provision was not closely examined by at least some members of the legislature. A proposed complete revision of the APA in 1963 failed. Davis, Recent Noteworthy Administrative Law Developments in Selected States, 17 AD. L. REv. 72, 76 (1964).

238 Colo. Rev. Stat. ANN. \& 3-16-4(4) (1963).

239 See, e.g., W. VA. Code ANs. § 29A-5-1 (c) (1966).

240 It should be noted once again that all conclusions as to the number of states having or not having a certain type of discovery may not be strictly accurate, since particular agencies may operate under statutes delegating authority to them which allow for discovery. In states having APA's, particular agencies have not been investigated; in states not having APA's, only the liquor licensing and medical practice boards have been researched. It is believed, however, that the findings represent an accurate picture of the state of the law among the states.

241 W. VA. CODE ANN. \& 29A-5-1(c) (1966).

242 N.D. CENT. CODE $\$ 28-32-09$ (1960).

243 UTAH CODE ANN. \$ 58-1-30 (1953).

244 W. VA. CoDE ANs. $\S 29 A-5-1$ (c) (1966). The APA covers liquor licenses, but if the licensee demands a hearing and loses, he must pay costs. Id. $\$ 60-7-13$ (d) (Supp. 1967).

245 FED. R. CTV. P. 26-37.

240 W. VA. R. CTv. P. 26-37.

247 UTAH CODE ANN. § 58-1-30 (1953).

248 UTAH R. CTV. P. 26-37.

240 N.D. CENT. CODE \& 28-32-09 (1960).

250 N.D.R. CIV. P. 26-37. 
Because the statute speaks of a "manner" of taking depositions, it is possible that the clause does not create a substantive right to take depositions, but only a right to take whatever kind of depositions the agency allows according to the rules regulating notice, time, and place for taking depositions in civil suits. Such an argument seems to place too much emphasis on the meaning of the word "manner" and overlooks the import of the whole statute. An Oklahoma statute ${ }^{251}$ which used the same language was held to create administrative discovery, ${ }^{252}$ thus indicating that courts believe the legislators to have used the term "manner" in a substantive sense.

Despite the similarity of language referring to discovery in the Utah, West Virginia, and North Dakota statutes, the availability of discovery may differ due to the different legislative histories in the respective states. Those courts in North Dakota and Utah which do not favor discovery rights in administrative hearings may use the following argument to deny such discovery: Unlike the situation in West Virgima, where the legislature did not enact the APA until seven years after it adopted broad civil discovery rules in $1959,{ }^{253}$ North Dakota ${ }^{254}$ and $\mathrm{Utah}^{255}$ enacted their broad civil discovery rules after they adopted their APA's. The differing chronologies have an important bearing on the determination of legislative intent, which may in turn vitally affect the scope of the discovery right. Where legislators enact a rule providing for depositions as in civil cases, the probability that they had a particular type of deposition in mind is very high. If depositions for discovery, rather than merely for the perpetuation of testimony, were in use in civil cases at the time the legislature enacted the administrative statute, its intent to implement discovery in administrative proceedings seems clear. Thus, even without using the term "discovery," the West Virginia statute estabhshes the legislature's intent to allow it. Where, lowever, the APA allowed depositions "as in civil cases" before adoption of broad discovery rules the legislature's intent is unclear because the legislators might not have intended a future change in the rules of civil procedure automatically to cliange admimistrative procedures by virtue of incorporation provisions in the APA. While it is possible to speculate that the legislature has acquiesced in the resulting

251 OrLa. Stat. AnN. tit. 75, § 315 (1965).

262 Brightmire v. District Court, 424 P.2d 425 (Okla. Crim. App. 1967). For a discussion of discovery in Oklahoma, see notes 259-62 infra and accompanying text.

203 W. VA. R. Cw. P. 26-37, at 243 (1966). See generally Harrison, The West Virginia Admintistrative Procedutre Act, 66 W. VA. L. REv. 159, 180 (1964).

254 Compare ch. 240, § 9, [1941] N.D. Laws 395-96 with N.D. CoDE ANN. § 31-05-01 (1943).

255 Compare UTAI CODE ANN. § 58-1-30 (1953) and id. § 79-130 (1943) with UTAB R. of Civ. P. 26 (1953) and UtAII CODE ANN. \$ 104-51-1 (1943). 
discovery by not passing subsequent legislation, it is perhaps more likely that the extension of discovery to the agencies was inadvertant, and that the legislators had not intended it.

Without statutes which explicitly authorize discovery, the respondent in a licensing adjudication may attempt to resort to broad legislative policies to overcome what appears to be an unfavorable legislative intent regarding a particular enactment. In the case of the states noted above, for example, North Dakota was the first state to enact an APA, ${ }^{250}$ the regulatory scheme designed in part to ensure parties of a minimal degree of procedural protection. Utah is among the few states to have adopted the liberal Federal Rules in toto, ${ }^{257}$ and is unique in proclaiming by legislative enactment an inherent right to security of occupation. ${ }^{258}$ These facts are some evidence of legislative acquiescence or approval of discovery in admimistrative proceedings.

Discovery rights in Oklahoma administrative hearings for license revocations and suspensions exist both by reason of court decisions and legislative act. The state's APA, patterned after the Model Act, provides that

[t]he agency, or any party to a proceeding before it, may take the depositions of witnesses, within or without the State, in the same manner as is provided by law for the taking of depositions in civil actions . . . . Depositions shall be admissable in any proceeding affected by this Act. ${ }^{259}$

Oklahoma does not have discovery rules based on the Federal Rules, and its deposition statute provides that they "may be used" for trial only when a witness is unavailable. ${ }^{200}$ However, in civil cases, the Oklahoma courts interpret this provision as restricting only the use of depositions and therefore allow parties to take depositions whether the deponent would be available at trial or not. ${ }^{261}$ The APA incorporates this rule, and a state court in 1967 held that under the more liberal evidence rule applicable to agencies, such depositions were admissible in proceedings under the

258 Ch. 240, [1941] N.D. Laws 393.

257 See UTAH R. Civ. P.

258 UTAF CODE ANN. \$ 58-1-1.1 (1953). But see UTAII CODE ANN. \& 32-4-8 (1953), providing that liquor licenses are revocable at any time with or without a hearing, "and in no such case need any cause be stated. The acts of the commission in ... denying or revoking licenses or permits shall not be subject to any review whatever . . .," except for fraud. The statute is probably rooted in Utali's Mormon heritage.

259 OrIa. Stat. AnN. tit. 75, $\S 315$ (1965).

260 Id. tit. 12, § 433 (1960).

261 See State ex rel. Westerheide v. Shilling, 190 Okla. 305, 123 P.2d 674 (1942); In re Abbot, 7 Okla. 78, 54 P. 319 (1898). 
APA. ${ }^{202}$ The effect, then, is to create a broad discovery right similar to the deposition rules in Wyoming.

The Virginia APA, like the North Dakota, Utah, and West Virginia rules, provides for depositions "to be taken and read as in actions at law. ${ }^{2203}$ As in North Dakota and Utal1, the administrative agency provision preceded the use of depositions for discovery purposes at law. ${ }^{264}$ The Virginia statute possibly las a narrower scope, lowever, since the authority supporting sucl discovery is only a rule of court ${ }^{265}$ rather than a legislative enactment. Since regulation of administrative procedure is particularly a matter of legislative concern-agencies usually derive their authority from legislative enactments ${ }^{268}$ - the Virginia courts may interpret the court rule as being inapplicable to the agencies.

In Kansas, depositions for discovery purposes may also be available. This state differs from those noted above, however, in two respects: First, the state's statutory provisions do not clearly create a discovery right by a simple cross-reference to broad civil discovery rules. Second, the state legislature has evinced no general policy regarding procedural riglts which could override a possible interpretation of the agency's deposition statute making it inapplicable for discovery. ${ }^{267}$

Kansas has no APA, but its regulatory act for the medical professions provides that "depositions may be used by either party"268 in license revocation or suspension proceedings. However, unlike many such statutes, ${ }^{209}$ the Kansas provision does not state that the parties may take or

202 Brightmire v. District Court, 424 P.2d 425 (Okla. Crim. App. 1967). It is arguable that the court misinterpreted the APA. Although the APA provides that depositions taken in the same manner as in civil suits "shall be admissable," the sentence following this may limit the admissabihty to instances in which a witness is unavailable. "[A]ll or any part of the deposition may be objected to at time of hearing, and may be received in evidence or excluded from the evidence ... in accordance with the law . . . with reference to evidence in courts of record ...." OKIA. STAT. ANN. tit. 75, \& 315(1) (1965). The court might have interpreted this provision as allowing the deposition of an available witness to be excluded from evidence, as cases have provided for civil cases.

203 VA. Code ANN. \$ 9-6.10(c) (1964).

204 Id. \$ 8-313 (1957) provides for depositions only where the witness will be unable to attend the trial. Rule of Court 3.23 (c), goverming actions at law, provides for discovery by deposition, mspection, copying, and photographing where the court is satisfied that a party in good faith desires access to evidence subject to the witness's control. Rule of Court 3.23 (c). This rule was adopted in 1954. Id. (1957). The APA was enacted in 1952. Ch. 703. [1952] Acts of Assembly 1146.

205 VA. CT. R. 3.23 (c).

260 See K. Davis, Administrative Law Text $\S 1.01$, at 2 (1959).

267 See ch. 303, § 60-226, [1963] Kan. Laws 618; ch. 343, § 44, [1957] Kan. Laws 771. In Oklahoma, the question of chronology and its interpretation has been mooted by the state court's decision allowing discovery. See notes 259-62 supra and accompanying text.

268 Kan. Gen. Stat. Ann. § 65-2844 (1964).

269 E.g., W. VA. CODE ANN. $\S 29 A-5-1$ (c) (1966). 
use depositions "as in civil actions." This makes it difficult to assess its significance. Although Kansas has biberal discovery rules, ${ }^{270}$ this does not clarify the scope of the administrative procedural right. However, it is arguable that in the absence of anything to the contrary, "depositions" have the same significance in administrative proceedings as in civil actions, and therefore, the statute grants discovery rights to the licensee.

In Iowa, Louisiana, and Mississippi deposition rights for licensing are more restrictive than under the Federal Rules, but they are precisely the same as exist in civil cases in those states. In Iowa jurisdiction over revocation and suspension cases involving physicians' licenses lies in the district courts. ${ }^{271}$ This may indicate either that administrative agencies have been slow to develop or that the legislature has recognized that license revocation is so important that courts should try such cases to insure maximum fairness. Iowa's rules of civil procedure, which govern the licensee's hearing, allow discovery although it is somewhat more limited than the Federal Rules. ${ }^{272}$ The practice of conducting hearings in court prevails as to physicians' licenses in Louisiana, where discovery rights are far more restrictive than in Iowa, ${ }^{273}$ and as to liquor licenses in Mississippi, where there is a minimal amount of discovery available in civil actions. ${ }^{274}$

As has been noted, ${ }^{275}$ the California supreme court, in Shively $v$. Stewart, ${ }^{276}$ formulated for the first time some rules of administrative discovery applicable to general agencies. ${ }^{277}$ At the very least, Shively seems to require prehearing discovery in cases of occupational or professional license revocations when the grounds for agency action is the commission

270 See Kan. Gen. Stat. ANN. \$§ 60-226 to 237 (1964).

271 IOWA CoDe ANN. \$ 147.58 (1949).

272 See Iowa R. CIv. P. 121-41 (1951).

273 LA. REv. STAT. ANN. § 37:1285 (1964), allows the agency to institute proceedings in any court of competent jurisdiction. Discovery is pernissible only as to certain items and under certain circumstances, but "investigation" is provided for although a suit has not been commenced. Id. \$ 13:4861-75 (1968).

274 MISS. Code ANN. $§ 10223$ (1952) provides for a court trial in hquor license revocation cases. The Mississippi deposition provisions were apparently intended to preclude discovery rights, but included within its exceptions are depositions of females, and instances wherc a particular claim or defense depends on a single witness. Id. \& 1699 (1956). The result may well be that discovery is available for hiquor sale licensees, but not for physicians, whose procedure is determined by an agency having jurisdiction over the revocation of medical practice licenses.

275 See notes 12-14, 129-33 supra and accompanying text.

27665 Cal. 2d 475, 421 P.2d 65, 55 Cal. Rptr. 217 (1966).

277 The California supreme court applied discovery procedures as in civil cases to disciplinary proceedings before the state bar in Brotsky v. State Bat, 57 Cal. 2d 287, 368 P.2d 697, 19 Cal. Rptr. 153 (1962). The court held, however, that the state bar "is not an administrative board in the ordinary sense. ... It is sui generis." $57 \mathrm{Cal} .2 \mathrm{~d}$ at 300, $368 \mathrm{P.2d}$ at 703, 19 Cal. Rptr. at 159. 
of a criminal act by the respondent. ${ }^{278}$ In Shively, the petitioners sought to subpoena statements which witnesses gave to the agency, copies of petitioners' bills, letters, documents, and materials and reports which investigators gathered. ${ }^{279}$ The court held that the petitioners were "clearly entitled" to discover the statements. ${ }^{280}$ An allegation that they did not have copies of the bills, letters, and documents requested was sufficient as to those materials; ${ }^{281}$ as to the investigative materials and reports, the court held that "an additional showing of need and specificity" was a prerequisite to discovery ${ }^{282}$ the court went on to hold, however, that respondents were entitled to "reasonable opportunity to make such a showing" and for this purpose could take depositions of the agency's attorney and executive secretary to determine whether there was good cause for the production of other unprivileged docunients. ${ }^{283}$ The government contended that the deposition of the agency's attorney would require his subsequent removal from the handling of the case, ${ }^{284}$ and that depositions of the executive secretary would result both in harassment and disruption of the normal functioning of agency affairs. ${ }^{285}$

\section{Miscellaneous Provisions Providing the Licensee with Information}

In addition to notice and deposition provisions, the licensee may be able to use certain other procedural devices to gain access to information needed for his case. Several states provide for prehearing conferences which allow the parties to simplify the issues or come to a settlement. ${ }^{286}$ The procedure is analogous to that which Federal Rule 16 contemplates. Unhike Rule 16, however, the parties must consent to holding the confer-

278 For reasons discussed in text accompanying notes 132-33 supra, the rules of discovery must probably be applied without regard to whether the respondent is subject to a criminal charge.

$27965 \mathrm{Cal} .2$ d at 481, 421 P.2d at 69, 55 Cal. Rptr. at 221 (1966).

$280 \mathrm{Id}$.

281 Id. at 481-82, 421 P.2d at 69, 55 Cal. Rptr. at 221.

282 Id. at 482,421 P.2d at 69, 55 Cal. Rptr. at 221.

283 Id.

284 Petitioners Brief for Rehearing at $35 \cdot 36$, Shively v. Stewart, 65 Cal. $2 \mathrm{~d} 475,421$ P.2d 65, 55 Cal. Rptr. 217 (1966).

285 Id. at 33-34. The Attorney General expressed dissatisfaction with other portions of the opinion. He contended that the legislature "never contemplated the subpoena duces tecum ... would be so abased as is now indicated by this court's decision. The situation is appalling . ..." Id. at 12. Even had there been legislative inaction, as the court claimed was the case, the rules would not be justified. "Silence is not consent. This court apparently in its desire to achieve a result has relegated this well recognized rule to the judicial waste basket." Id. at 23 .

280 Fla. Stat. \$ 120.25(6) (1965); IND. ANN. Stat. \$ 63-3007 (1961); N.M. Stat. ANN. § 67-26-9 (1961); WASH. REv. CODE ANN. § 34.04.090(8) (f) (Supp. 1967); W. VA. Code ANN. § 29A-5-1(d) (1966); WIs. Stat. ANN \$ 227.08 (1957). Cf. ArIz. Rev. Stat. ANn. § 32-1451(B) (Supp. 1967); VA. Code ANN. § 9-6.10(a) (1964). 
ence. ${ }^{287}$ Colorado and Arkansas are the only states which make such conferences mandatory. ${ }^{288}$ As a party is unlikely to consent if he fears that he has more to lose than gain, and as agencies beheve discovery works to their disadvantage, agencies would probably reject a conference where there is a possibility that an independent hearing officer will try to put pressure on the agency to allow discovery-even if such discovery would cover both parties. Prehearing conferences will perhaps, on occasion, be effective as a discovery device, but the role of the statute in these cases will be merely to codify existing informal adjudication procedures. In this area, discovery which is discretionary with the agency has always existed. $^{288}$

In most states, however, lawyers who are involved in license suspension or revocation proceedings will not have the benefit of statutory language which grants any discovery rights. The lawyers must consult the APA or statutes delegating powers to individual agencies. If the APA excludes very few agencies from its coverage and its provisions generally stress procedural fairness to the respondent, it is arguable that the legislature omitted explicit provisions for various discovery devices only because it beheved such rules would be inappropriate in all cases and for all types of adjudication. The legislature might have intended instead to allow discovery by delegating general powers to the hearing officer.

Florida's new APA, for instance, covers all agencies except the legislature, courts, and governor. ${ }^{290}$ The statute gives broad discretionary powers to the hearing officer to "take or cause depositions to be taken whenever the ends of justice would be served thereby, to regulate the course of the hearing, to hold conferences for the settlement or simplification of the issues by consent of the parties, to dispose of procedural requests or similar matters, and to enter any order to carry out the purposes of the statute."201 In the federal jurisdiction, a provision for the taking of depositions whenever the ends of justice would thereby be served is included in the APA, ${ }^{292}$ but it has not been held to create discovery rights. ${ }^{203}$ In

287 E.g., FIA. STAT. \$ 120.25(6) (1965).

288 Colo. Rev. Stat. ANN. § 3-16-4(4) (1963); ART. StAT. ANN. § 5-709(c) (6) (Supp. 1967). Since Arkansas provides for discovery, id. \$ 5-709(c) (5), the role of the prehearing conference is much the same as in civil litigation, with the distinction that discovery in the administrative action depends on the presiding officer's discretion. See id.

289 Where there is discovery provided by other provisions, then of course the prehearing conference is a useful incident of the discovery process. An example of such a prehearing conference is found in West Virginia. W. VA. CODE ANs. $\$ 29 A-5-1$ (d) (1966).

290 FrA. Stat. \& 120.21(1) (1965). Agency is defined as the governing body of any state board, commission, or department.

201 Id. \& $120.25(4)-(8)$.

2925 U.S.C. $\$ 556$ (c) (4) (Supp. II, 1965-1966).

293 Cf. Sperry \& Hutclinson Co. v. F.T.C., 256 F. Supp. 136 (S.D.N.Y. 1966). 
Florida's statute, as well as in other states having similar rules, ${ }^{294}$ however, the great discretionary power of the hearing examiner would allow for discovery if he were so disposed. ${ }^{295}$

States having APA's based on the Model Act provide simply for an opportunity for all parties to "present evidence and argument,"206 and delegate authority to the agencies to "adopt appropriate rules of procedure for notice and hearing in contested cases."297 These vague provisions are more frequent than are the general provisions of the Florida APA. It is conceivable that such provisions might allow discovery as a necessary part of the "opportunity to present" evidence. However, because the agency is an adversary in the adjudication, and has the power to grant or deny discovery, it is unlikely that it would consider discovery an "appropriate" rule of procedure. Missouri, instead of using the Model Act's words-"presentation and argument"-provides for a reasonable opportunity for "the preparation and presentation" of evidence. ${ }^{298}$ This language focuses on the relationship between the capacity to present evidence and the ability to prepare it; but, so long as the rule making

294 Indiana has administrative regulations similar to the Florida provisions. See InD. AdMIN. Rules \& ReGs. ANN. (12-402) -2 to 4 (1967). Rule (12-402) -3(1), provides that the commission shall afford parties appearing "every reasonable opportunity and facility for information." Rule (12-402) -4 duplicates the Florida statute in defining the hearing officer's powers.

The effect of this statute is to mitigate soniewhat the harshness of another statute which grants absolute discretion to the agency to revoke or suspend liquor licenses without the opportunity for judicial review. IND. ANN. STat. § 12-443 (1956).

295 For an argument that discovery rights are intended by statute, see Comnent, Procedural Due Process: Florida's Uniform Administrative Procedure Act, 21 U. MTAMI L. REv. 145,163 (1966). Some indication of the legislative intent may be provided by the Florida Bar's final draft of discovery rules for criminal proceedings. In addition to creating a broad right to discover statements, confessions, reports, and lists of witnesses, it would go far beyond the present practice of almost all other states by allowing the defendant to take depositions "of any person other than a confidential informer ... who may have information relevent to the offense." Legislation, Florida's Proposed Rules of Criminal DiscoveryA New Chapter in Criminal Procedure, 19 U. FLA. L. Rev. 68, 96 (1966). As of March 1967, the rules had been approved by the Florida Bar's Board of Governors, and had been submitted to the supreme court where it was still pending. CLE Presents, 41 FLA. B.J. 182 (1967). Vermont has such a procedure. Vr. Stat. ANN. tit. 13, § 6721-27 (Supp. 1967). Florida has gone far also in allowing discovery in workmen's compensation cases. For discussion, see notes 352-58 infra and accompanying text.

290 HawaII Rev. Laws § 6C-9(c) (Supp. 1965); Idaho Code ANN. § 67-5209(c) (Supp. 1967); Mo. ANn. Code art. 41, § 251 (1957); Mrce. Comp. Laws \$ 24.104 (1967); MINN. Stat. ANn. § 15.0418 (1967); Neb. Rev. Stat. § 84-913 (1966); Ore. Rev. Stat. § 183.420 (1967) ; R.I. GeN. Laws ANN. § 42-35-9 (Supp. 1967); Wask. Rev. Code ANv. § 34.04.090(2) (Supp. 1967). Other states provide no more than an opportunity to "present evidence." N.M. Stat. ANn. \$ 67-26-8 (1961); N.C. Gen. Stat. \$ 90-14.2 (1965); S.C. Code ANn. \$ 4-57 (1962) ("produce evidence").

207 E.g., WASE. Rev. CODE ANN. $\$ 34.04 .090$ (7) (Supp. 1967).

298 Mo. AnN. Stat. § 536.063(3) (Supp. 1967). 
power lies with the agency, and so long as it is quite reasonable to interpret "preparation" as requiring the agency only to give the respondent reasonable time, agencies should not be expected to provide as radical an innovation as discovery. Massachussetts ${ }^{299}$ and Wisconsin ${ }^{300}$ require opportunity for a "full and fair" hearing. This, in practical effect, probably accomplishes no more than the Model Act-oriented statutes, since a "full and fair" hearing is synonymous with the right to present evidence and argument.

The legislatures in a number of states have not even provided by statute for the opportunity to present evidence. ${ }^{301}$ Illinois' provisions regulating liquor licenses provide for a hearing after notice "in accordance with rules and regulations established by [the agency] not inconsistent with law."302 South Dakota's statute governing the revocation of physicians' licenses provides only that there is a right to hearing upon notice. ${ }^{\text {g0a }}$ The agencies may liave subpoena power, but this does not seem to create any additional rights for the respondent. That many states have the barest minimum of procedural requirements for hearings does not automatically preclude discovery, of course. As was the case in California-a state whose only APA section which was even vaguely related to discovery consisted of a general subpoena power, ${ }^{304}$ and whose legislature twice considered and failed to pass administrative discovery bills ${ }^{305}$ - the courts might take the initiative and create forms of discovery for administrative proceedings. Past history suggests New Jersey to be sucli a state, despite the absence of significant procedural requirements in its license statutes. ${ }^{300}$

\section{Summary}

At least thirteen states have created for the respondent in a license revocation or suspension adjudication a right to some form of discovery. In some of these states, to be sure, the discovery is greatly restricted and may not represent a legislative or judicial policy choice, but in others the state lias consciously sought to incorporate discovery devices into agency

299 Mass. Gen. LAws ANn. ch. 30A, \& 10 (1966).

300 Wrs. STAT. ANN. § 227.07 (1957).

301 See, e.g., PA. STAT. ANN. tit. 63, § 410 (Supp. 1967) (physician). Maine's APA creates an office of hearing commissioner, which has responsibility for adopting, amending and repealing rules of procedure in contested cases. ME. Rev. STAx. ANN. tit. 5, 82403.5 (1964). This office has jurisdiction over license revocations. Id. $\$ 2301.2$.

302 Irr. ANN. StsT. ch. 43, \& 150 (Smith-Hurd Supp. 1967).

303 S.D. CoDE $\$ 27.0310$ (Supp. 1960).

304 CAL. Gov'T CoDE $\$ 11510$ (West 1966).

$\because 305$ See note 8 supra and accompanying text.

${ }^{306}$ See Davis, New Jersey's Unique Conception of "Fair Play" in the Administrative Process, 10 Rotgers L. Rev. 660 (1956). Professor Davis discusses the "extremely high standards of fair play" which New Jersey's supreme court has imposed. 
hearings. These states usually himit discovery to depositions, but depositions are probably the most useful discovery device and sufficient for the hicensee's needs. Besides their value as an informational tool, depositions allow the adversaries to confront each other face to face and test the relative strengths and weaknesses of each other's case.

Without provisions requiring discovery, the agency's adversary position and its zeal in prosecution may preclude the possibility of extending discovery rights in other states without further judicial or legislative action. Above all else, the penalty of revocation, when combined with the agency's. role in the adjudication, creates a need for further extensions of discovery in other states.

\section{III}

\section{WITHDRAWAL AND MIODIFICATION OF FRANCHISES}

One common definition of a "franchise" is a governmental privilege in the hands of a subject. ${ }^{307}$ It usually signifies a grant by the government of a right to maintain a public utility within a given area or to use a public asset such as the airways. The characteristics which perhaps most distinguish franchises from licenses are the fewer number of franchise holders for more important activities, and the consequent need for strict regulation to determine when, how, and whether the state is to allow the activity.

The interest of large segments of the public in the activity conducted under the franchise ${ }^{308}$ and the fact that the government in awarding franchises often creates partial or total monopolies argue strongly for regulation. Franchises differ also from occupational or professional licenses in that there is no authority to engage in the activity which the franchise covers comparable to the often acknowledged right to engage in a particular profession. Thus, the authorization to engage in the occupation of driving a taxi might be a "right" from the standpoint of the individual cabdriver, and the certificate the state usually gives him is called a license. However, the authority to operate a fleet of taxis is usually termed a franchise, which is only a "privilege," as it involves questions of public need for the service and inquiries into alternative means of transportation. The courts have not made altogether clear either the line differentiating licenses from franchises ${ }^{308}$ or the essential characteristics of a franchise, but these characteristics will serve the purposes of this section: to examine

307 Commonwealth v. Arrison, 15 S. \& R. 127, 130, 16 Am. Dec. 531, 533 (Pa. 1827); see Kilgarlin v. Martin, 252 F. Supp. 404, 440 (S.D. Tex. 1966).

308 See generally Englewood v. Crabtree, 157 Colo. 593, 601, 404 P.2d 525, 529 (1965); Lansing v. Lansing, 356 Mich. 338, 97 N.W.2d 128 (1959).

309 See, e.g., City of Chicago v. Rothschild \& Co., 212 III. 590, 72 N.E. 698 (1904); Cumberland Tel. \& Tel. Co. v. Calhoun, 151 Ky. 241, 151 S.W. 659 (1912). 
the extent of available discovery devices in adjudications involving the termination or modification of businesses affecting important public interests.

The respondent's need for discovery may be as pronounced in administrative proceedings which will determine the existence or scope of a franchise as it is in a license revocation hearing. The state may, for instance, decide that a recently approved extension of a bus line's operation is damaging previously existing transportation companies and is generally having a deleterious effect on economic conditions in the state. The basis for the agency's contentions may be a complex set of findings compiled by a team of agency investigators and experts. The enfranchised company may find the cost of conducting its own investigation prohibitory. Without discovery, the respondent has no substantial basis for challenging the agency's findings. Yet, discovery may for legitimate policy reasons be unavailable as the following example indicates.

One business affecting important public interests is intrastate commercial air transportation. The state has an interest in fostering the development of intrastate aviation as well as in closely regulating the persons who can enter the field. The effect of these interests is to encourage an attitude in the administrative agencies which emphasizes long range public policy considerations. Typifying such considerations is the "certificate of public convenience and necessity,"310 which represents the official authorization to conduct the activity. One statute ${ }^{311}$ which delegates power to an aeronautics agency and deals with the question of intrastate airlines indicates the considerations which are to guide the agency in issuing such certificates by declaring that the policy of the state is:

... to regulate intrastate commerce . . . as to foster sound economic conditions in such commerce and among air carriers in the public interest; promote adequate, economical and efficient service... [and] without ... unfair or destructive competitive practices, pro-

310 E.g., AIA. Code tit. 4, § 39(E) (1960). In regulating intrastate air commerce, most states do not have certificates of public convenience and necessity. Many of such states provide for revocation only on grounds of wrongdoing. As such, these regulatory acts are similar to professional and occupational licensing provisions. See, e.g., MINN. STat. ANn. $\S 360.018(6)$ (1966).

311 AIA. CODE tit. 4, $\S 38-62$ (1960). Only fifteen state statutes deal with the special problem of intrastate airline commerce. Of these, only a few are as comprehensive as the Alabama statute. E.g., Mont. Codes ANN. § 1-323 (Supp. 1967). In the other states, provision is commonly unade for a special airline certificate, but a clear policy for the agency to follow is not enunciated. See, e.g., S.C. CoDs ANN. \$ 2-81 (1962). In the remaining states, the problem of intrastate air commerce is not independently treated, but comes within the provisions regulating individual pilots. Such regulation usually consists only of a requirement that the pilot hold a federal license or certificate and that the aircraft be similarly certified. E.g., N.Y. GeN. Bus. LAw \$ 241, 243 (McKinney 1957). The effect of such regulation is to delegate authority to the federal government regarding intrastate airlines. 
vide for competition to the extent necessary to assure the sound development of an air transportation system . . . $\mathbf{3 1 2}$

Because the role the legislature created for the agency is primarily that of fostering aviation progress, it is likely that the evidence the agency accumulates, in administering the above statute, to support a proposed franchise modification or rejection of the individual's application will consist largely of legislative, and not adjudicative fact. Professor Davis states that legislative facts do not usually concern the immediate parties, but help the tribunal decide questions of law and policy and to exercise discretion. ${ }^{313}$ These facts are less likely than adjudicative facts-those facts which relate directly to the parties and their activities, businesses, and properties ${ }^{314}$ - to require an administrative hearing for a fair determination. The agency's expertise makes it the most appropriate body for deciding such questions. ${ }^{315}$

Where the granting of a franchise depends on "sound economic conditions," and a determination of what constitutes "destructive competitive practices," adjudicative facts are not in issue, since the agency's findings describe a general economic condition rather than the respondent's financial stature. Naturally, if there is no right to a hearing, ${ }^{316}$ because such legislative determinations and political judgments should remain in the agencies' discretion and expertise- then there is no right to discovery. ${ }^{\mathbf{3 1 7}}$

\section{A. Discovery in Franchise Proceedings}

At times franchise suspensions, revocations, and modifications may be necessary to foster "sound economic conditions." For example, the intrastate air industry is young and perhaps cannot withstand "destructive competition." For these reasons it might be wise policy to leave to the agencies exclusively the ultimate decision as to the industry's needs. However, such reasoning which might otherwise justify withdrawal overlooks the investment an entrepreneur makes after he receives a franchise. Per-

312 ATA. CoDE tit. 4, § 41 (1960).

313 K. Davis, ADMTNISTRATIVE LAw Text § 7.02, at 116 (1959).

314 Id. at 115 .

315 See $i d$. at 116. Professor Davis argues that facts pertaining to the parties and their businesses and activities are facts which are best known to the parties. Therefore, they are in a good position to rebut or explain evidence that bears upon these adjudicative facts. Id. ${ }^{316}$ See id. $\$ 7.02$.

${ }^{317}$ Although such legislative considerations are often the basis for administrative action regarding franchises, all but a few states apparently restrict the operation of these legislative policies to proceedings in which franchises are created or modified as opposed to withdrawn. See, e.g., Ky. Rev. Stat. Ann. § 183.570(1) (1962); Alaska Stat. § 02.05.100 (1962). Arkansas's statute provides that the commission may also suspend or revoke any certificate previously granted "where the public interest so demands." ARK. Stat. AnN. \$ 74-410 (1957). Accord, as to suspensions, Kr. Rev. Stat. ANN. \$ 183.570(6) (1962). 
haps because of this, most of the states issuing certificates of public convenience and necessity require hearings before an agency may modify or revoke such a certificate on the grounds of public convenience. ${ }^{318}$ The statutory procedures for conducting the hearing, however, are either minimal ${ }^{310}$ or nonexistent, ${ }^{320}$ and the respondent must argue for a right to discovery on alternate grounds.

Kentucky law, for exanple, authorizes the commission to "alter, amend, modify or suspend any such certificate ... if the public convenience and necessity so require" ${ }^{1321}$ after it has given notice and a hearing. Apart from the imvestigatory power granted to the agency ${ }^{322}$ and the bare requirement of legal notice, the only statutory procedural guideline is that proceedings should be "as sunmary and simple as possible." Such paucity of procedural detail probably is traceable to the legislative considerations in favor of giving broad discretionary authority to the agencies.

An additional reason which militates especially against procedures for discovery is that massive amounts of detailed information involving rates, service, equipment, and other technical matters usually support a decision to modify an airlines certificate which is based on legislative fact. Discovery in these circumstances may prove unduly burdensome on the agencies. For example, Arkansas' statute sets out certain factors which the agency must consider before issuing a certificate. ${ }^{324}$ Included in the list are such matters as the transportation service which any railroad or motor carrier already maintains, the effect which such proposed transportation niay have upon other forms of transportation service, and "any other matters showing the necessity or want of necessity" for the airlines service. These same factors are bikely to determine also the question of modification and revocation.

Granting the franchise holder the right to discover all information relevant to the agency decision with respect to these factors would create an unlimited investigative power in the certificate holder. This investigative power would constitute an oppressive burden on the agency. For example, there is a real threat that the respondent in each case would present interrogatories to the agency demanding answers to questions about every procedure the agency follows to reacli its ultimate decision as to the want

318 E.g., Ataska Star. $\S 02.05 .030$ (a) (1962) (APA coverage); Mont. Rev. Codes ANN. § 1-323 (Supp. 1967).

319 See, e.g., Ala. CODE tit. 4, § 44(G) (1960), and id. tit. 48, §301(26) (1958).

320 See, e.g., Mont. Rev. Codes ANv. § 1-323(10) (Supp. 1967).

321 Ky. Rev. Star. ANN. § 183.570(6) (1962).

322 Id. § 183.032 .

323 Id. \& $183.032(1)$.

324 ARK. StaT. ANN. \& 73-1762 (c) (1957). 
of "necessity" for a particular air route. Such a decision as to "necessity" represents the accumulated experience of many officials in the agency having expert knowledge. The standard of relevance would not be adequate to limit discovery in these circumstances.

\section{B. Federal Treatment of Franchise Rights}

The federal courts and Congress have often treated franchises in a manner which is incompatible with the state legislatures' apparent policy of restricting the procedural riglits of the individual holding the franchise. Because in many franchise situations the government has granted to individuals noncompetitive or semicompetitive shares in the economy, ${ }^{325}$ franchises seem to come very much within the idea of government gratuities whicl create only privileges. Nevertheless, Congress and the federal judiciary have considered some franchises to create vested property rights. In $C A B$ v. Delta Air Lines, Incorporated, ${ }^{326}$ the agency had ordered an alteration of a certificate of public convenience and necessity pursuant to the Federal Aviation Act of $1958 .^{327}$ The question presented was whether the $C A B$ could so alter the certificate without granting the minimal procedural rights of a hearing and notice. The Supreme Court, holding for the airlines, said that Congress was vitally concerned with "security of route"-that is, with assuring "the carrier that its investment in operations would be protected insofar as reasonably possible." 328 The decision rested on legislative history, but the Court's emphasis on the franchise holder's investments ${ }^{329}$ indicates that reliance in the large investment situation may create some sort of vested property right.

An earlier federal case, Standard Airlines, Incorporated v. CAB, ${ }^{330}$ refrained from finding a property right in franchises, but its decision approached such a declaration. The case involved a similar question of the right to a learing prior to $\mathrm{CAB}$ administrative action. Here, too, the court focused on the investment and the airline's resulting reliance. The court took note of the "substantial investments" in the enterprise, ${ }^{331}$ and determined that, although there was "no general property right in its registration," a suspension which would have the effect of destroying a "substantial property investment" required an opportunity for a hearing. ${ }^{332}$

325 See, Reich The New Property, 73 YaLe L.J. 733, 735 (1964).

326367 U.S. 316 (1961).

32749 U.S.C. \& $1371(\mathrm{~g})$ (1964).

328367 U.S. at 324.

329 See id. at 324-25.

330177 F.2d 18 (D.C. Cir. 1949).

331 Id. at 20.

332 Id. 
Some state cases have held that franchises may create property rights. ${ }^{333}$ It may be that the property right is really a form of estoppel by reliance-arising from the substantial investment the franchise holder has made. The resulting procedural protections which a court deems such an estoppel requires, however, may be similar to those arising under a property right.

\section{Summary}

The large investment induced by the grant of a franchise has impressed the federal courts. Implicit in the federal cases is the idea that an individual should be able to rely on the government grant at least in cases in which he is not guilty of gross wrongdoing. If the courts ultimately take the view that what is common to both hicense revocation proceedings and franchise termination where a single individual holds the franchise is the threatened loss of livelihood, rather than the extent to which a gratuity is involved in the particular form of government largess, then they may require discovery in both types of adjudication. It is questionable, however, whether such coincident treatment is warranted. The courts' emphasis on "security" has the effect of linking together franchise and license proceedings, and subordinating the issue of legislative as opposed to adjudicative facts. This ignores a fundamental difference between the two proceedings. The absence in many franchise cases of adjudicative facts may make discovery an impediment to effective administration by the agencies. One solution might be to require the agencies to submit, at some time prior to the hearing, a brief report which will apprise the agency's adversary of the relevant facts and considerations which were taken into account in its decision. Where the report is disproportionately small in relation to the complexity of the impending litigation, a court might order discovery of particular relevant information, or order a more complete prehearing report.

Where adjudicative issues are the basis for agency action in terminating a franchise, the argument presented for discovery in terms of the consequences for the individual is the same as that present in license revocation or suspension cases. ${ }^{34}$ Some states allow the agency to impose a fine of up to one thousand dollars for a violation of agency rules and regulations. ${ }^{335}$ In these cases, the similarity to a criminal proceeding is so clear

333 E.g., Finney v. Estes, 130 Colo. 115, 273 P.2d 638 (1954); Mayor v. Canton Co., 186 Md. 618, 47 A.2d 775 (1946).

334 Some states treat all proceedings involving intrastate airlines as licensing. As such, the procedures may be controlled by the APA in the same manner provided for other occupational licensees. See, e.g., FLA. STAT. \$\$ 120.21(1), 120.22, 330.261 (1965).

335 E.g., VA. CODE ANN. \& 56-167 (1959). In other states, the provisions for violation come within the penal code, and imprisonment is provided for. E.g., TEx PEN. CODE ANN. \& 1137 (b) (6) (1961). 
that there seems to be little reason to require less stringent procedural standards merely because an agency tribunal rather than a court makes the determination of wrongdoing.

IV

DISCOVERY IN WORKMEN'S COMPENSATION PROCEEDINGS: THE AGENCY AS ARBITER

\section{A. The Industrial Accident Board}

A major difference between adjudication of workmen's compensation claims and license revocation and franchise withdrawal hearings is that, in the former, the agency does not assume the role of adversary but rather acts as impartial arbiter between the parties. A leading authority has remarked that

in the spectrum of administrative agencies, ranging as they do from executive regulatory and rule-making bodies to quasi-judicial tribunals deciding individual cases between particular private parties, the compensation commission while deciding controverted claims is as far toward the judicial end of the spectrum as it is possible to go without being an outright court. ${ }^{336}$

Workmen's compensation procedure is generally summary and informal, taking its tone from the beneficent and remedial character of the legislation. ${ }^{337}$ The proceedings referred to in this section of the Comment are the typical ones in which the employer and employee contest eitler the clain of injury, its extent, or the ainount to be paid.

Because of the agency's role, a broad power to make procedural rules which is delegated to an industrial accident commission is likely to be of a different nature than it would be if it were delegated to an agency whose role is to guard the public's health and safety. In the latter situation, it would be difficult for an advocate of discovery to rely solely on the general rulemaking power wlich the agency is to exercise to secure for the respondent a "fair hearing" in order to obtain discovery rights; in the former case the agency lias nothing to lose by allowing discovery, ${ }^{338}$ and so there is little reason why it should not grant it so long as the social interests the agency safeguards are not endangered thereby.

The workmen's compensation agencies were especially created to hear industrial accident claims. This was done partially to provide a more

336 2 A. LARSON, THE LAW OF WorkMEn's CoMrPensation $\$ 79.90$ (1961).

337 Id. \& 78.10.

338 As used in this section, discovery does not include the right to take medical examinations of the employee. Such statutes are provided for in most states, and for this reason alone discovery in workmen's compensation cases is more extensive than in license revocation cases. For a discussion, see notes 378-79 infra and accompanying text. 
liberal compensation scheme than would exist in the courts ${ }^{330}$ and partially because the legislature believed that agency adjudication would prove to be more efficient and less expensive than court trials. ${ }^{340}$ Modern statutes reflect the public desire for liberal benefits to the injured employee ${ }^{341}$ and provide an expeditious claim procedure which ensures early compensation without placing too great a burden on the state or employer. These statutes frequently call for a procedural system whicl "shall be as summary and simple as reasonably may be," ${ }^{\prime 42}$ or proclaim that the hearing board or commission "shall not be bound by technical or formal rules of procedure," and require the arbiter to concluct the hearing in a manner to "ascertain the substantial riglits of the parties."

\section{B. Discovery in Workmen's Compensation Hearings}

\section{By Virtue of Broad Commission Powers}

The effect of the broad discretionary authority which the statutes invariably grant to the commission is to allow the one who hears the case to be a rather freewheeling arbiter seeking substantial justice without undue concern for technical rules whicl might impede his search. ${ }^{344}$ Sucl a picture is perhaps an exaggeration, but the statutory language does create a situation in which it is difficult in many instances to determine whether discovery is available. In fourteen states, the statute is silent about depositions by the parties, discovery, and the right to prepare, present, or receive evidence. ${ }^{345}$ Likewise, it does not define the powers of the commission or hearing officer so as to determine whether he may declare discovery rights, although the statue may give to the commission

339 See 2 A. Larson, The LaW of WorknIen's Comprearsation \& 78.10 (1961).

${ }^{340}$ See Riesenfeld, Workmen's Compensation and Other Social Legislation: The Shadow of Stone Tablets, 53 CaIIF. I. REv. 207, 210 (1965).

341 See id. at 208-09.

342 E.g., Atasta Stat. \& 23.30.005(d) (1962); IDamo CODE ANN. § 72-601 (1949).

343 E.g., Minn. Stat. ANn. \& 176.411(1) (1966); N.Y. Workmen's Comp. \& 118 (McKinney 1965).

${ }^{344}$ The most extreme example of this discretionary power is found in the Oregon statute which provides that the hearing officer-"except as otherwise provided"-may conduct the hearing "in any manner that will achieve substantial justice." ORE. REv. STAT. § 656.283(6) (1965).

${ }^{345}$ Ariz. Rev. Stat. Ann. \& 23-942 (1956); Conn. Gen. Stat. AnN. § 31-174 (1960); Det. Code ANN. tit. 19, \& 2121(a) (1953); HAWAII Rev. Laws § 97-57 (1955); IDamo CoDE ANN. § 72-601 (1949); INd. ANN. Stat. § 40-2217 (1965); KAN. Gen. Stat. ANN. § 44-549 (1964); KY. Rev. Stat. ANN. \$342.260, 342.270 (1962); La. Rev, Stat. ANN \& 23:1317 (1964); N.H. Rev. Stat. ANn. § 281.41 (1966); ORE. Rev. Stat. \& 656.283 (1965); S.D. CODE \& 64.0604 (1939); Tex. Rev. Civ. Stat. AnN. art. 8307, § 4 (1967); Vt. Stat. Ann. tit. $21, \& 602$ (1959). 
fairly broad investigatory powers. ${ }^{340}$ In these states, then, it is uncertain whether any discovery devices are available.

It is often possible, however, in these states and in states having statutes allowing parties to take depositions only for nondiscovery purposes, ${ }^{347}$ that the commission's investigative powers, when combined with its impartial role, will result in the availability to the parties of information gathered by a commission investigation. Thus, where the agency has power to take testimony of witnesses or parties by means of depositions, ${ }^{348}$ or to subpoena documentary evidence, ${ }^{349}$ it may in its discretion give such depositions or reports to the parties. ${ }^{350}$ Pennsylvania provides a more formal procedure: The results of agency investigations are part of the record and are open to the parties' inspection. ${ }^{351}$ If this provision is applicable prior to the hearing, then the statute's effect is to make the agency an agent of the parties for discovery purposes.

The Florida case of Kirk v. Publix Super Markets ${ }^{352}$ indicates how workmen's compensation boards are likely to provide discovery to the parties where the statutes are only general in nature. The relevant state statute authorized the commission to "make or cause to be made such investigation as it considers necessary in respect of the claim." ${ }^{353}$ The

340 E.g., IDAHO CODE ANN. $\$ \S 72-601,72-604$ (1949), providing that the commission has power to examine "such of the books and records of the parties as relate to questions in dispute," and shall make "such inquiries and investigations as shall be deemed necessary." An especially broad provision is CoNN. GEN. STAT. ANN. \$ 31-174 (1960), providing simply that the commissioner shall investigate "in such manner ... as is best calculated to ascertain the substantial rights of the parties." The purpose of the investigation being explicitly stated, the statute implies that the parties should be made aware of the findings at the earliest possible time. As is the case in license revocation or suspension proceedings, see note 200 supra, the statutes often give deposition power to the agencies, but this is solely an incident to their investigative powers, and cannot be spoken of as "discovery." E.g., KaN. Gen. Stat. AnN. \$ 44-549 (1964); MD. ANN. Code art. 101, § \&(a) (1957).

347 See Alaska StaT. § 23.30.115 (1962); Ird. AnN. Stat. ch. 48, § 153 (Smith-Hurd 1950); ME. Rev. Stat. ANn. tit. 39, § 93 (1964); Mass. Gen. Laws ANN. ch. 152, 5 (1958); N.J. Rev. Stat. § 34:15-65 (1937); N.C. Gen. Stat. § 97-80(a) (1965) and id. \$ 8-71 (1953); OHIo Rev. Code ANN. \$ 4123.09 (Page 1965) and id. \$ 2319 (Page 1954); PA. Star. ANN. tit. 77, \$ 835 (1952); S.C. Code ANN. §§ 72-64, 26-601, 26-704 (1962); Wash. Rev. Code AnN. $\$ 51.52 .100$ (1962); Wis. Stat. ANn. $\$ 102.17$ (1)(b), (1) (bm) (Supp. 1967).

348 E.g., KAN. GeN. STAT. ANN. § 44-549 (1964).

349 FLA. STAT. $\S 440.33$ (1965).

350 Such a discretionary power would be warranted by a provision that the "hearing shall be conducted in a manner to ascertain the substantial rights of the parties," e.g., MnNo. STar. ANN. \$ 176.411(1) (1966), or by a provision which requires that the procedure shall be "as summary as may be under this law." E.g., Tex. Rev. Crv. STax. AvN. art. 8307, \$ 4 (1967).

351 Pa. Stat. Ann. tit. 77, § 831 (1952).

352185 So. 2d 161 (Fla, 1966).

353 FIA. StaT. \$ 440.25(3) (a) (1965). 
legislature had also delegated the usual subpoena power to the agency to enable it to compel the production of books, papers, documents, and other evidence. ${ }^{354}$ The court upheld as a "reasonable interpretation," the commission's view that these statutes authorized it to order the employee to produce for the employer's attorney copies of reports from physicians who had either previously examined or treated him, and records relating to his admission to two hospitals. ${ }^{355}$ Moreover, the court held that the commission's subpoena power removed all doubt as to the discovery question ${ }^{356}$ although the statute seemed to contemplate production of materials for the benefit of the commission rather than the parties.

Significantly, the commission, in dismissing the employee's claims because of his refusal to comply with the discovery orders, relied on the sanctions which the Florida discovery rules provide. ${ }^{357}$ The court held that the adoption of the discovery rules applicable in civil proceedings to the agency proceeding was a proper exercise of the commission's authority to make reasonable rules and regulations necessary for handling its business. ${ }^{358}$ If the Florida commission and supreme court are at all typical, ${ }^{360}$ discovery devices may be available to the parties in workmen's compensation proceedings whether there is specific statutory authority providing for such discovery or not. At least this is a possibility where the information which an employer seeks relates to the nature and extent of the employee's injury and without access to which there is often no possibility of adequate preparation owing to the technical nature of the controversy.

\section{By Virtue of Specific Statutory Language}

In thirteen states, discovery is clearly available to the parties in workmen's compensation proceedings by virtue of language specifically addressed to discovery or "depositions." " In most instances such discovery

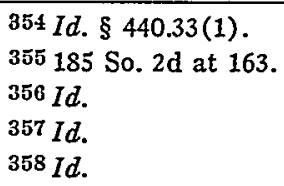

359 Many statutes have substantially the same wording. E.g., CAI. LABOr CODE $\$ 5708$ (West 1955); Conn. Gen. STAT. Rev. § 31-174 (1960); NEb. Rev. Stat. § 48-168 (1960). 360 See ALA. Code tit. 26, § 304 (1958) and tit. 7, §§ 474, 477-90 (1960); Colo. Rev. Stat. Ann. \& 81-14-23 (1963) and Coro. R. Civ. P. for Courts of Record 26; Cax. Lador Code $\S 5710$ (West Supp. 1967) and CaL. Crv. Pro. Code $\S 2016$ (West Supp. 1967); GA. Code ANN. \$ 114-706 (1956); Iowa Code ANN. \$ 86.21 (1949) and Iowa R. CIv. P. 140-43; Mrnn. Stat. ANn. § 176.411(2) (1966) and MnNv. R. Civ. P. 26; Mo. AnN. Stat. \$ 287.560 (1965) and State ex rel. Consolidated Underwriters v. Rose, 322 S.W.2d 939 (Kansas City, Mo. Ct. App. 1959) ; Mont. Rev. Codes ANv. $\S 92-813$ (1964) and Mont. R. Civ. P. 26; N.M. Stat. ANn. § 59-10-13.9 (1960); N.D. Cent. Code \$\$ 65-02-11, 28-32-09 (1960), N.D.R. Civ. P. 26; UtaA COde ANN. \$ 35-1-29 (1953) and UtaE R. Civ. P. 26; Civ. P. 26; UtaH Code ANn. § 35-1-29 (1953) and Utah R. Civ. P. 26; VA. Code ANN. \$ 65-91.1 (1950) and Va. Court (Civ.) R. 3.23(3) ; Wyo. Stat. Anin. § 27-118 (1957) and Wyo. R. Civ. P. 26. 
arises by virtue of provisions in the statute allowing the parties to take depositions according to the rules applicable in civil cases. The fact that discovery rules were promulgated in many of these states subsequent to the relevant workmen's compensation provision may indicate the absence of conscious legislative choice in creating broad discovery rights in workmen's compensation proceedings. However, this is unlikely to detract from the substantive right created because there is no hostile agency seeking to use a chronological argunent to defeat discovery. In this way, the situation differs from the problem of legislative intent in the licensing agencies. ${ }^{301}$

In at least four other states, discovery rights in favor of the parties may exist, depending on the interpretation of ambiguous statutory language. ${ }^{362}$ The ambiguity is traceable to the language providing that the "commission may cause depositions to be taken." New York, Nevada, and West Virginia have such statutory language. ${ }^{363} \mathrm{It}$ is unclear whether only the commission has the riglit to take depositions for purposes of investigation $^{304}$ or whether the commission can grant this right to the parties. It is possible that the words imply only that the commission's agents may take depositions, but it is just as likely that the words cover situations in which a party makes a motion for discovery to the commission whicl in turn orders the taking of depositions. The commission would thus be the causal agent. A New York court has interpreted such a statute to authorize discovery by the parties. ${ }^{365}$

The provision of the fourth state, Arkansas, provides that the commission may cause depositions to be taken "in such manner as it may direct." ${ }^{366}$ This discretionary power seems merely to confirm the availability of discovery to the parties where the commission chooses to interpret the causation clause broadly.

In some states, courts, rather than administrative agencies, conduct workmen's compensation proceedings pursuant to special rules. The parties can make a strong case for the availability of discovery devices in

361 See text accompanying notes $253-55$ supra.

362 See Ark. Stat. ANN. \& 81-1328 (1960) and id. § 28-348 (1962); Nev. Rev. Stat. $\S 616.240$ (1963) and NEV. R. Crv. P. 26; N.Y. WorkMEN'S COMP. LAW $\$ 121$ (McKinney 1965) and N.Y. CIV. PRAC. LAW $\S 3102$ (McKinney 1963); W. VA. CODE ANN. $\$ 23-1-11$ (1966) and W. VA. R. Crv. P. 26.

363 N.Y. WORKMEN's COMrP. LAW § 121 (McKinney 1965); NEv. REv. STAT. $\$ 616.240$ (1963); W. VA. CODE ANN. § 23-1-11 (1966).

364 A statute which does reserve this power exclusively for the agency might provide that the commission shall have power "to take depositions." E.g., MD. ANN. CODE art. 101, $\S 8$ (a) (1957).

365 Eberhardt v. Sonsade Realty Corp., 21 App. Div. 2d 951, 251 N.Y.S.2d 264 (1964). The case involved discovery hy interrogatories, but the court assumed that the statute allowed the parties to make use of discovery.

360 ARK. Stat. ANN, § 8I-1328 (1960). 
two of these states, Nebraska and Tennessee, due to the statutory provisions which authorize the court to exercise powers which judges possess while trying cases in courts of general jurisdiction. ${ }^{367}$ Nebraska limits such powers to those involved in the taking of depositions or the examination of witnesses in ordinary civil cases. The state allows the taking of depositions for discovery purposes. ${ }^{368}$ Since a judge exercises his powers in ordering a party to submit to a deposition or in making other appropriate orders, Nebraska's statute seems to provide for discovery. In Tennessee, there are no specific limits on the extent to which the judges' powers in trying cases in courts of general jurisdiction are applicable to workmen's compensation proceedings; hence the statute seems to create a riglit to use all available discovery devices. In Tennessees this includes interrogatories. $^{369}$

New Mexico provides that the district court which hears the case must advance the proceeding on the calendar and conduct it in summary fashion. ${ }^{370}$ The legislature, in making discovery procedures applicable to compensation proceedings, addressed itself directly to the potential conflict between discovery and expedition by requiring that discovery devices be available only after the court, on a party's motion and after hearing, finds that "good cause exists [and] that the evidence to be obtained will probably be material to the issues of the cause."371 By requiring good cause for the use of discovery, $\mathrm{New}$ Mexico can afford to allow the use of interrogatories and other discovery techniques as well as depositions. The statute guards against the potential delay whicl is always present in the use of discovery by imposing a judicial control at the outset of the proceedings. The state thus avoids the often ineffectual efforts of courts to control discovery by the use of orders for the protection of the parties ${ }^{372}$ after delay has already ccurred.

Other states in which agencies conduct workmen's compensation proceedings also have attempted to control the use of discovery devices in such hearings. Minnesota gives the commission power to prohibit the taking of a deposition, but does not specify the procedures to be followed or whether a party can take a deposition only upon a showing of good

367 Neb. Rev. Stat. \$ 48-162 (1960); Tenv. Code ANv. \$ 50-1018 (1966).

368 Neb. REv. Stat. § 25-1267.01-.02 (1964).

360 TENN. CODE ANN. § 24-1201 (Supp. 1966) and id. § 24-1101 to 07 (1955).

370 N.M. STAT. ANN. \$ 59-10-13.10 (1960).

371 Id. \& 59-10-13.9. The state's highest court has ruled that the requirement of a motion is to be strictly complied with. It is error to admit depositions where no motion has been made even if notice was given and no objections were entered. Reed v. Fish Eng'r Corp., 74 N.M. 45, 390 P.2d 283 (1964).

372 E.g., N.D.R. Civ. P. 30 (b). 
cause. ${ }^{373}$ Virginia requires the party seeking to use depositions to set forth the materiality of the evidence. ${ }^{374}$

Anıong the states which explicitly authorize certain forms of discovery, most allow it as of right. ${ }^{375}$ Three states make the availability of discovery a matter lying within the discretion and judgment of the agency; ${ }^{376}$ in addition, in the three states whose statutes say the agency "may cause depositions to be taken, ${ }^{\prime 377}$ if the correct interpretation of the ambiguity is that in favor of the parties' deposition rights, those rights are still contingent on the agency's discretion. The statutes which create such a discretionary power may be more in keeping with the pohicy of providing in workmen's compensation cases for a means of attaining substantial justice expeditiously and inexpensively.

The most commonly used form of discovery in workmen's compensation cases is probably the employer's statutory right to take medical examinations of the employee. ${ }^{378}$ The results of this and other physical examinations are so often the crux of the controversy, and the examination procedure so pecuhar to workmen's compensation proceedings, that to speak of this as "discovery" for the purpose of this Comment obscures the limited extent to which the states have adopted the more common discovery tools. It is, of course, a method of obtaining essential information prior to the hearing and, as such, best typifies the purpose and value of discovery. Probably all the states have medical examination provisions, ${ }^{379}$ while less than half the states allow depositions or interrogatories. ${ }^{380}$ The character of the adjudication explains the disparity. The burden of having to present an adequate defense without such a procedure in a workmen's compensation case, where the sole issue may be the nature, cause, or extent of the injury, would be so intrinsically unfair that such a procedural device in favor of the employer is absolutely essential for a fair hearing. Because the employer's interest in discovering the claimant's true medical condition is not comparable to the interest in discovery of other parties in other adjudications, it is best to think of such a discovery device as being in a separate category.

373 See Minn. Stat. Ann. \$ 176.411(2) (1966).

374 VA. Code ANN. \$ 65-91.1 (1950).

375 See, e.g., CAI. LABOR CODE $\$ 5710$ (West Supp. 1966).

370 See Minn. Stat. ANn. $\$ 176.411$ (2) (1966); N.M. Stat. Ann. § 59-10-13.9 (1960);

VA. Code ANN. \$ 65-91.1 (1950).

377 Nev. REv. StaT. $\$ 616.240$ (1963); N.Y. WORKMIEN's CoMTP. $\$ 121$ (McKinney 1965); W. VA. Code ANN. \$ 23-1-11 (1966).

378 E.g., CAL. LABOR CODE $\$ 4050-56$ (West 1955).

370 E.g., Kan. Gen. Stat. ANN. \$ 44-515 (1964).

380 See notes $360,362,367$ sulpra for a list of nineteen states which may allow discovery. 


\section{Summary}

Discovery may be available in workmen's compensation proceedings in almost all the states-either by specific statutory grant to the parties or by virtue of the broad authority delegated to an agency to promulgate discovery rules or release the fruits of discovery to the parties. Depositions are commonly the only device available, although at least three states allow other forms of discovery. ${ }^{381}$ The relatively widespread availability of discovery contrasts sharply with hearings involving revocation or suspension of hicenses, or withdrawal of franchises, where in the vast majority of states discovery is most likely unavailable.

Two factors may explain the relatively substantial acceptance of discovery in industrial accident proceedings. First, the matter in issue is often of a technical nature and acquaintance with the opposition's claims and investigation of the subject matter of the action at as early a point in the adjudication as possible has an expediting effect. A referee of workmen's compensation proceedings has argued that the proper utilization of discovery methods hastens the disposition of the adjudication, materially assists in the early settlement of meritorious claims, and often brings about the dimissal of claims having little or no justification. ${ }^{382}$

It is perhaps true that discovery is particularly helpful in workmen's compensation cases, but the same referee argues that discovery expedites all types of litigation. ${ }^{383}$ To explain why the agencies have received discovery as well as they have in workmen's compensation cases requires noting the second factor: The removal of the agency's adversary posture creates a greater possibility for an objective appraisal of the requirements of fairness and expeditious proceedings. Moreover, eliminating the agency as a party to the adjudication results in a situation in which the parties are more nearly equal, and consequently, as is the case in civil litigation, in the belief they both may gain or lose equally from discovery. It is ironic that where discovery is most needed to provide equal opportunities for presentation of evidence, as in licensing, the agency's opposition may thwart any introduction of discovery; where, however, the threat of agency prejudice is least present, as in workmen's compensation proceedings, the possibilities for the introduction of discovery are greatest. That discovery may be less necessary in workmen's compensation proceedings

381 See N.M. Stat. AN. \$ 59-10-13.9 (1960); Tenn. Code AnN. § 50-1018 (1966) and id. §§ 24-1201 (Supp. 1966), 24-1101 to 07 (1955); Wyo. Stat. ANN. § 27-118 (1957) and Wyo. R. Crv. P. 26-37. In Eberhardt v. Sonsade Realty Corp., 21 App. Div. 2d 951, 251 N.Y.S.2d 264 (1964), the New York court allowed the use of interrogatories. However, the case involved an employee living in Germany at the time of the action.

382 Carroll, Discovery Procedures Under the Missouri Workmen's Compensation Law, 15 J. Mo. B. 320 (1959).

383 Id. 
than in other adjudications does not, of course, argue against its adoption there. The industrial accident boards' ability to cope with a large volume of cases quickly and inexpensively is a central policy justifying their existence. That unany workmen's compensation agencies have accepted or encouraged discovery is certainly indicative of discovery's value both in expediting as well as in allowing procedural fairness. The policy of expeditious adjudication argues also, lowever, for the adoption of a system of discovery whicli is forcefully regulated so as to provide procedural fairness while preserving administrative aims.

\section{$\mathrm{V}$ \\ THE CONTROL AND CREATION OF DISCOVERY}

\section{A. Discovery Regulated}

From a respondent's viewpoint, what is involved in the question of discovery in administrative proceedings is simply whether or not he is going to get an opportunity to present a more adequate defense. Such an opportunity may depend either on finding lielpful information otherwise unknown, or preparing to meet hostile evidence which his adversary miglit otherwise reveal only at the hearing. To some agencies, this opportunity represents a threat to the adminstrative functions: Either by delaying the proceedings, allowing invasion of agency files, or permitting continued threats to public liealth and welfare. A procedure by whicli one party may require another to answer questions and to allow him to searcli through files outside a courtroom will necessarily present dangers. Unless the parties will voluntarily refrain from ever asking improper questions, seeking confidential information or material which is the work product of the adversary attorney, or using discovery to delay or larass, it will not be possible to eliminate these dangers altogether. The question in each case must be whether legislative or judicial action can effectively reduce such dangers while providing for discovery.

The need for prehearing discovery seems to be the greatest in proceedings in which the agency attempts to revoke a practitioner's license. The threatened loss of liveliliood and the existence of controversies involving adjudicative facts in such hearings requires an opportunity for the respondent to be able to contest the agency's claims as effectively as possible. Even in cases in which discovery requires additional time for disposition of the case, the requirements of fairness are no less present. A system of discovery for administrative proceedings does not, however, preclude controls.

One such control, which already exists in the Federal Rules, is the court's power to make orders for the protection of parties and depon- 
ents. ${ }^{384}$ The court may, after notice and a showing of good cause, prohibit depositions, himit the available discovery devices or the scope of the inquiry, or make "any other order which justice requires to protect the party or witness from annoyance, embarrassment, or oppression." This protective power is easily adaptable to administrative proceedings. An administrative discovery statute might also add a statement of policy regarding the hearing officer's use of such authority. It should make clear the requirements of an administrative system for expeditious handling of adjudication and the consequent need for flexibility of discovery procedure.

The different problems arising in the three types of administrative adjudication upon which this Comment has focused demonstrate the need for flexible procedures. The role of the agency in the case, the nature of the sanction which the agency imposes, and the subject matter of the hitigation are only a few of the factors which have a bearing on the determination of suitable rules of discovery. There is no reason why discovery procedures should be absolutely uniform. ${ }^{386}$ There is also no need to eliminate any particular form of discovery beforehand. For example, depositions might not ordinarily be permitted of a member of the agency; there may be instances, however, in which an agency member's involvement in a case is so great that depositions should be allowed.

In instances in which the hearing date is far off, the parties might be allowed to use whichever devices they choose; where the hearing follows closely upon the pleadings, the hearing officer might require the parties to use alternative devices to obtain information if in his judgment such a restriction will not result in loss of the opportunity to discover relevant information.

A factor which may substantially affect the adjudication's progress is the availability of an interlocutory appeal procedure. Such a device may be particularly dangerous in administrative adjudication, since the agency often initiates action in response to an imminent threat to public health or safety. If a respondent is profiting from illegal activity, the longer he can put off a final determination, the better off he is. ${ }^{387} \mathrm{~A}$ right to take inter-

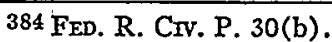

$385 I d$.

${ }^{386}$ Some critics of the administrative process have objected to the great diversity of procedures among the agencies, See, e.g., Vanderbilt, Administrative Procedure: Shall Rules Before Agencies Be Uniform? 34 A.B.A.J. 896, 898 (1948). Professor Davis has been a supporter of the need for diversity. See $1 \mathrm{~K}$. Davis, Admenistrative Law Treatrse \& 8.02, at 517 (1958).

387 In the California Legislature's hearings on discovery, the presiding officer of the Office of Administrative Procedure told of similar problems in the accusation plase, "[W]hen we lear a case in which the hearing officer proposes the revocation of a liquor license along about Christmas time, we can know full well we're going to get a request for a 
locutory appeals makes interminable delays possible. Yet there are situations in which the prejudice to the party from an erroneous ruhing by a hearing officer is so great, and reversal so certain, that it may make hittle sense to require the parties to present their cases and await a decision before appealing. One solution might be to make the standard of interlocutory review more stringent. This, however, will not deter the respondent whose interest is merely to delay. Another solution might be to give the hearing officer authority to determine whether an appeal is permissible. If the liearing is likely to be lengthy, immediate appeal may save all parties concerned time and effort; if the liearing can be concluded within a few hours or one day, the hearing officer could require a final decision before allowing appeal from discovery orders. During the time in which an appeal is taken, the decision will be in effect and the danger to the public from the respondent's activities will be eliminated.

Where interlocutory appeal is available, the danger of frivolous appeals can be reduced by allowing the appellate tribunal to assess costs against both the respondent and his attorney ${ }^{388}$ equal to the agency's expenses. This would give the reviewing court power similar to that which a trial court lias under the Federal Rules to require parties seeking orders on frivolous grounds to pay expenses. ${ }^{389}$ The test which the Federal Rules use-whether there was substantial justification for a refusal to answer or for a question ${ }^{300}$ - seems reasonable to apply also to the question of frivolous appeals. Where the danger to the public from continued operation of the respondent's business is great, the hearing officer might require either a final decision on the merits or allow the agency to seek a temporary restraining order while the appeal is taken.

Another instance in which the hearing officer's authority can effectively reduce the problems arising from the use of discovery is in the use of prehearing conferences. Some states provide for such a conference on a voluntary basis. ${ }^{301}$ The Federal Rules give courts the authority to make these conferences mandatory in civil actions. ${ }^{392}$ They usually take place

transcript on that case ... Sometimes it may take a reporter as much as 40 days . . ." Discovery Proceedings, supra note 10, at 73-74 (testimony of Mr. Coan).

388 The Federal Rules provide for an assessment against the attorney for costs when the court finds he has advised his client to refuse to answer questions without sufficient cause. FED. R. Crv. P. 37 (a).

389 FED. R. CTr. P. 37 (a), (c).

300 Id.

391 See notes 286-88 supra and accompanying text.

392 FED. R. Crv. P. 16. Until recently, California courts made the pretrial conference mandatory. CAL. SURER. CT. (CTv.) R. 208 (West 1964). In 1967, the Judicial Council amended the rule to provide for conferences only at the request of a party or by order of the court after "consideration of the necessities of that particular case." CaIIF. SUPER. Cr. (Crv.) R. 208 (West Supp. 1967). 
after the parties have completed discovery. ${ }^{303}$ Authors have considered pretrial conferences to be a technique which courts can effectively use to define the issues, limit the evidence which the parties may introduce at trial to essential matter, and gain admissions from the parties. ${ }^{304}$

Because of the need to cut down on delay and special problems, such as privilege, which are likely to arise in administrative proceedings, it may be wise to provide for sucl a conference before discovery devices are available to the parties. ${ }^{395}$ There will be many cases in which discovery is not necessary; therefore, the hearing officer might hold prehearing conferences only where either of the parties malses a request. At such a prediscovery conference, the hearing officer could learn whether the respondent is likely to seek materials or information which the agency will claim to be privileged. He might then conduct a hearing on the issue. If it cannot be resolved by agreement, he could schedule an in camera proceeding for the purpose of examining the materials in issue. ${ }^{306}$ If the respondent seeks to take depositions of high-level officials in the agency and must show good cause for such a deposition, a hearing could be conducted at the conference. Good cause for inspection and copying might also be determined at the conference.

For hearings in which legislative facts are central to the controversy, as is the case with franchise hearings, an early conference might be particularly beneficial. If discovery is not practicable in such cases, the hearing officer can make a ruling before the parties have made preparations. In addition, he might order the agency to state the main findings which led to its decision and give a sampling of the agency's evidence to the respondent in order to allow effective preparation for contesting such findings. Often, such materials will be of public record which individuals may have a statutory right to inspect, but the "right to know" is not always clear and is usually sharply limited by definitions of "public writings" and "records." "307

303 See Louisell, Discovery and Pre-Trial Under the Minnesota Rules, 36 MINN. L. REv. 633, 665 (1952).

394 See Kaufman, Have Administrative Agencies Kept Pace with Modern Court-Developed Techniques Against Delay?-A Judge's View, 12 AD. L. BuLL. 103 (1959); Louiscll, supra note 393 , at $660-68$.

305 See Pickering, The Pre-Trial Conference, 9 Hastings L.J. 117, 122-25 (1958).

396 Cf. United States v. Gleason, 265 F. Supp. 880 (S.D.N.Y. 1967). For a discussion of the in camera discovery procedure used in the Gleason criminal trial, see notes 170-72 and accompanying text.

397 In California, for mstance, a litigant must first establish that what he sceks disclosed is a "record." For problems as to this requirement, see Comment, Inspection of Public Records Under California Law, 50 CALIF. L. REv. 19 (1962). One of the special problems is that if a document requires later approval or is merely "preliminary," it need not be open to inspection. See Comment, Discovery Prior to Administrative Adjudications-A Statutory Proposal, 52 CALIF. L. REv. 823, 825-29 (1964). After the litigant luurdles this 
Procedures authorizing the hearing officer to exercise broad discretionary powers presuppose the existence of independent hearing officers. In workmen's compensation proceedings, the agency's role of arbiter creates in the minds of the parties an impression of impartiality. Where the hearing officer can restrict rights to discover information, to use depositions, or to appeal to the courts, public confidence in the administrative process requires not only impartiality in fact, but also a belief among those affected that they have received fair treatment. In California, such confidence was, until recently, ${ }^{398}$ undermined by a statute ${ }^{399}$ authorizing any agency to appoint its own hearing officers in lieu of using those in the Division of Administrative Procedure. ${ }^{400}$ Nor was the appearance of unfairness totally illusory. One practitioner saw the danger of such choice in the following terms:

An agency that, perhaps for budgetary reasons, prepares cases against only the most derelict of its licensees, and then only after past warnings to them have been unavailing, wants a result rather than procedural safeguards. The same is true of an agency engaged in "cleaming up a mess," whether for political or other reasons. ${ }^{401}$

If states are to introduce discovery into the agencies, there is a need for the same flexibility of discovery procedure as there is for flexibility in other administrative procedures. The diversity of subject matter which the administrative system regulates warrants such treatment. Hearing officers, being in charge of the adjudication, are the obvious people to entrust with the task of tailoring discovery to fit the needs of the parties and of the administrative process in the particular case and generally. Greater responsibility for decisionmaking, however, requires greater independence of judgment. The situation calls for a separately financed pool of hearing officers similar to that used in California upon which the agencies rely in all adjudications and the exercise of judicial restraint in reviewing the action of such independent hearing officers.

\section{B. Discovery Created}

Determining that discovery procedures ought to be extended to administrative adjudication is only the first step towards actually making

first obstacle, it is still possible that the record will come within the statutory exceptions from the "right to know." Id. Finally, the public information statutes are no aid in discovering information from parties other than the agencies.

398 The statute was amended in 1961, and now all hearings under the APA are conducted by officers in the Office of Administrative Procedure. CAx. Gov'r CODE $\S 11502$ (West 1966).

390 Ch. 867, \& 1, [1945] Cal. Stats. 1628.

$400 \mathrm{Ch} .869, \S \S 2,3$, [1945] Cal. Stats. 1637.

401 Kuchman, The Role of the Hearing Officer: A Private Practitioner's Point of View, 44 CaLfF. L. Rev. 212, 215 (1956). 
such procedures available. Which branch of government is to make the ultimate decision is a question that is still open. Other problems relating to the scope and form of these procedures also demand resolution. What exceptions, if any, should exist to the use of discovery? How is discovery to be controlled? What devices are to be eliminated or added?

In the administrative law area, whatever discovery exists is largely the product of legislative action, although there have been a few decisions which have broadened discovery rights by statutory construction. ${ }^{402}$ The major exception to this general rule is California, where the supreme court has made the first move toward creating a discovery right. ${ }^{403}$

This assumption of responsibility by the legislature contrasts with the situation in the criminal law area where the courts have assumed primary responsibility for creating rules of discovery. When the legislature has acted, it has often been merely to codify court-created rules. ${ }^{404}$ In promulgating discovery rules for civil litigation, the legislatures have been the instigating force. The explanation for the dissimilarity of treatment which different kinds of adjudication have received may provide answers to whether legislative or judicial action is most appropriate in the creation of administrative discovery. In criminal cases, a finding against the defendanit may result in loss of freedom; the imbalance in resources and resulting opportunities to present evidence favors the prosecution. ${ }^{405}$ Defeat in civil litigation or some administrative adjudications, on the other hand, usually signifies only a monetary loss; moreover, the private parties are more hkely equal than is the case in criminal prosecutions. Although discovery may help in expediting all types of proceedings, the threat of congested dockets is not comparable to the danger of depriving the defendant of a fair chance to gain acquittal by closing off avenues of possible inquiry.

In view of the exigencies involved in criminal cases, it is not surprising that the courts, upon becoming sensitive to the problem, should have taken the initiative in creating rules of discovery rather than waiting for the legislatures to act. ${ }^{406}$ Where, however, the primary value in the adoption of discovery is the speedier disposition of cases and the dismissal of

${ }^{402}$ See, e.g., Kirk v. Publix Super Markets, 185 So. 2d 161 (Fla. 1966). For a discussion of this case, see notes 352-58 supra and accompanying text.

403 See Shively v. Stewart, 65 Cal. 2d 475, 421 P.2d 65, 55 Cal. Rptr. 217 (1966).

404 Compare People v. Wolff, 19 Ill. 2d 318, 167 N.E:2d 197 (1960), with Irx. ANN. SThT. ch. 38 , \& 114-10 (1964). The statute concerns a right to discover confessions, while the case is broader in allowing discovery. The statute was enacted three years after the Wolf case. Ch. 38, § 114-10, [1963] IIl. Laws 2386.

405 See Goldstein, The State and Accused: Balance of Advantage in Criminal Procedure, 69 YaLe L.J. 1149 (1960).

${ }^{406}$ See $_{\text {; }}$ e:g., People v. Riser, 47 Cal. 2d 566, 585, 305 P.2d 1 (1956), cert. denied, 353 U.S. 930 (1957). 
claims having no merit, and where there is nothing inherent in the nature of the adjudication which makes unfairness inevitable, different policy considerations are relevant. In civil litigation, one such consideration is that the responsibility for major changes in the way civil causes are tried should rest with the representatives of the people. In the administrative law area, such a consideration is the fact that the legislature has delegated its authority to the agencies and, in doing so, has prescribed rules of procedure and has continued to exercise supervisory authority over the agency's affairs. The courts' belief that better rules might be established for handhing admimistrative actions is not a sufficient reason for vitiating this legislative authority on the grounds that the legislature, by inaction, contemplated judicial action. Nor is the fact that greater justice may be a byproduct of more expeditious handling of agency adjudication sufficient reason to preempt the legislature; such an argument would be as applicable to all questions of responsibility for procedural reform. Absent a sanction which is greater in effect than monetary loss, initiative for creation of discovery rights in administrative proceedings in which the parties are likely to be near-equals should rest with the legislature:

Workmen's compensation actions are the type of proceedimgs in which the dangers to the parties resulting from the unavailability of discovery are not such as demand immediate action, whether legislative or judicial. To be sure, discovery is a valuable procedural tool in enabling more adequate preparation, expediting the actual trial, and most importantly, ensuring the parties of an opportunity to obtain information relevant to their claims and defenses. The question, lowever, is whether in the ordinary case these benefits warrant judicial preemption of a legislative function. The answer inust be no.

License revocations and suspensions and ternination of certain types of franchises differ from workmen's compensation proceedings in several respects. First, the withdrawal of a license or franchise can signify the loss of a profession or investments and is often accompanied by the inlposition of a stigma. Second, the respondent cannot usually count upon the presence of a strong, impartial arbiter who has the opportunity to rely on liberal agency policy and rules regarding discovery in license and franchise proceedings. In addition, there is usually an inequality between the parties as to access to information before the hearing. These factors may make immediate action imperative; if the legislature does not act, judicial action would be justifiable here whereas it would not be in extending discovery to workmen's compensation proceedings.

Expertise is another element which one might consider-depending on the role one assigus the expert in society-in determining whether the initiative for creating discovery should lie with the courts or legislature. 
Arguments as to the respective expertise of courts and legislatures, however, look both ways. Among a body comprised of individuals from many assorted fields, there is bound to be a greater variety of expertise than one can ordinarily find in the courts. Furthermore, the legislature is able to draw on sources of information which are not available to the courts. On the other hand, while the legislature may be better equipped to deal with the substantive matter which is subject to agency regulation and to understand the peculiar problems which may arise in adjudication involving particular subject matter, the courts are certainly more familiar with the nature of trial practice in general and with the effects of discovery on litigation.

If expertise alone were the determinant, the legislature might be the most appropriate body for determining whether, in light of the subject matter with which a particular agency deals, discovery should be available; the courts might be best suited to carry out the legislative policy by establishing the procedures determining when, how, and under what circumstances discovery is available. For instance, it is for the legislature to find that discovery devices can be a significant aid to the parties in speeding up adjudication involving the award of a new bus route. The nature of the evidence may be so complex that the liearing officer would otherwise lave to grant continuances in order to avoid delaying tactics. But because of their experience with the various discovery devices, it should still be for the courts to determine whether unlimited interrogatories, depositions, or some combination of both, are most likely to aclieve the desired results. The legislature may in its investigations ascertain what the litigation is about; the courts know the potential of the various discovery devices for accomplisling legislative purposes.

A determination of the respective roles of the legislature and courts in creating discovery rights must take into account the urgency of the party's needs as well as the policy of leaving responsibility for major procedural innovations in the agencies to the legislature. Ideally, both legislature and courts lave a role to play within the area of their expertise in creating discovery rights.

\section{CONCLUSION}

The need for a flexible system of prehearing discovery in the administrative agencies varies in proportion to the presence in the adjudication of three major factors: (1) The possible imposition of a sanction essentially punitive in nature; (2) the presence of the agency as an adversary; and (3) the determination of adjudicative facts as essential to the outcome. The need for discovery is greatest in cases in which an individual faces 
the loss of his license or franchise to engage in a profession or occupation because of alleged wrongdoing.

In these cases, the imposition of a stigma on the individual, the accusatorial role of the agency, and the punitive nature of the agency's sanction, whereby the certificate holder is prohibited from engaging in his vocation or loses his franchise, links these proceedings to criminal cases. This, in turn, creates a demand for procedural protections which are constitutionally required for criminal trials, and which are as essential to a full and fair hearing in an administrative tribunal. Recent developments indicate discovery may be one of these constitutionally required procedures.

For the purpose of assuring fairness to the parties, a formal discovery system is less necessary in workmen's compensation cases, where the agency has a nonaccusatorial role; its value as an aid to expeditious treatment of such cases and in allowing preparation, however, are arguments in favor of granting broad discretionary authority to the hearing officer to provide for discovery where the circumstances warrant it. It is hkely that formal discovery rules would meet less resistance in such proceedings where the agency acts as an arbiter than in any other type of administrative action.

In those franchise adjudications involving legislative facts, the basis for agency findings is based largely on complex data and expert judgment; the tremendous burden which discovery would place on the agencies in these circumstances defeats the purpose for which these agencies were created. While discovery can act as an expediting force in all proceedings, the franchise holder-more than any other recipient of government largess -takes the franchise coguizant that the government may one day have to withdraw it because of interrelated series of events over which he has no control. These factors call for an intermediate discovery procedure supervised by the hearing officer.

At the present time, discovery practices existing in civil litigation are largely unknown in the licensing agencies. Several states, however, have provisions allowing the use of discovery by depositions, although it is unclear in some of these states whether the legislature intended to create discovery procedures. At least one states has incorporated the federal rules of discovery into administrative proceedings. Miscellaneous provisions may also allow discovery in certain circumstances. In workınen's compensation proceedings, statutory provisions customarily give broad discretionary authority to the agency and the hearing officer to provide procedures which are in the interests of ascertaining the substantial riglits of the parties. The means by whicl a litigant can gain access to informa- 
tion known only to his adversary appear to be greatest in these proceedings.

One traditional theory which underlies the agencies' reluctance to provide discovery is the doctrine that government largess is in the nature of a privilege and that agency sanctions are not quasi-criminal. Courts have begun to challenge both aspects of the theory. Its demise may clear the path for a reevaluation of the place of discovery in administrative procedures.

Leonard I. Margolis 